\title{
Sea surface temperature variability in the central-western Mediterranean Sea during the last 2700 years: a multi-proxy and multi-record approach
}

\author{
Mercè Cisneros $^{1}$, Isabel Cacho ${ }^{1}$, Jaime Frigola ${ }^{1}$, Miquel Canals ${ }^{1}$, Pere Masquée ${ }^{2,3,4}$, Belen Martrat ${ }^{5}$, Marta Casado M $^{5}$ \\ Joan O. Grimalt ${ }^{5}$, Leopoldo D. Pena ${ }^{1}$, Giulia Margaritelli ${ }^{6}$, and Fabrizio Lirer ${ }^{6}$ \\ ${ }^{1}$ GRC Geociències Marines, Departament de Dinàmica de la Terra i de 1'Oceà, Facultat de Geologia, \\ Universitat de Barcelona, Barcelona, Spain \\ ${ }^{2}$ Institut de Ciència i Tecnologia Ambientals \& Departament de Física, Universitat Autònoma de Barcelona, \\ Bellaterra, Spain \\ ${ }^{3}$ School of Natural Sciences and Centre for Marine Ecosystems Research, Edith Cowan University, \\ Joondalup, Australia \\ ${ }^{4}$ Oceans Institute and School of Physics, The University of Western Australia, Crawley, Australia \\ ${ }^{5}$ Institut de Diagnosi Ambiental i Estudis de l'Aigua (IDAEA), Consell Superior d'Investigacions \\ Científiques (CSIC), Barcelona, Spain \\ ${ }^{6}$ Istituto per l'Ambiente Marino Costiero (IAMC)-Consiglio Nazionale delle Ricerche, Calata Porta di Massa, \\ Interno Porto di Napoli, 80133, Naples, Italy \\ Correspondence to: Mercè Cisneros (mbermejo@ub.edu)
}

Received: 28 September 2015 - Published in Clim. Past Discuss.: 18 November 2015

Revised: 10 March 2016 - Accepted: 13 March 2016 - Published: 7 April 2016

\begin{abstract}
This study presents the reconstructed evolution of sea surface conditions in the central-western Mediterranean Sea during the late Holocene (2700 years) from a set of multi-proxy records as measured on five short sediment cores from two sites north of Minorca (cores MINMC06 and HERMC-MR3). Sea surface temperatures (SSTs) from alkenones and Globigerina bulloides $\mathrm{Mg} / \mathrm{Ca}$ ratios are combined with $\delta^{18} \mathrm{O}$ measurements in order to reconstruct changes in the regional evaporation-precipitation $(\mathrm{E}-\mathrm{P})$ balance. We also revisit the $G$. bulloides $\mathrm{Mg} / \mathrm{Ca}-\mathrm{SST}$ calibration and readjusted it based on a set of core-top measurements from the western Mediterranean Sea. Modern regional oceanographic data indicate that Globigerina bulloides $\mathrm{Mg} / \mathrm{Ca}$ is mainly controlled by seasonal spring SST conditions, related to the April-May primary productivity bloom in the region. In contrast, the alkenone-SST signal represents an integration of the annual signal.

The construction of a robust chronological framework in the region allows for the synchronization of the different core sites and the construction of "stacked" proxy records in order
\end{abstract}

to identify the most significant climatic variability patterns. The warmest sustained period occurred during the Roman Period (RP), which was immediately followed by a general cooling trend interrupted by several centennial-scale oscillations. We propose that this general cooling trend could be controlled by changes in the annual mean insolation. Even though some particularly warm SST intervals took place during the Medieval Climate Anomaly (MCA), the Little Ice Age (LIA) was markedly unstable, with some very cold SST events mostly during its second half. Finally, proxy records for the last centuries suggest that relatively low E-P ratios and cold SSTs dominated during negative North Atlantic Oscillation (NAO) phases, although SSTs seem to present a positive connection with the Atlantic Multidecadal Oscillation (AMO) index. 


\section{Introduction}

The Mediterranean is considered one of the most vulnerable regions with regard to the current global warming (Giorgi, 2006). This high sensitivity to climate variability has been evidenced in several studies on past natural changes (Rohling et al., 1998; Cacho et al., 1999a; Moreno et al., 2002; Martrat et al., 2004; Reguera, 2004; Frigola et al., 2007; Combourieu Nebout et al., 2009). Palaeo-studies focussed mostly on the rapid climate variability in the last glacial period have shown solid evidence of a close connection between changes in North Atlantic oceanography and climate over the western Mediterranean region (Cacho et al., 1999b, 2000, 2001; Moreno et al., 2005; Sierro et al., 2005; Frigola et al., 2008; Fletcher and Sanchez-Goñi, 2008). Nevertheless, climate variability during the Holocene, and particularly during the last millennium, is not so well described in this region, although its understanding is crucial for placing the nature of the 20th century trends in the recent climate history (Huang, 2004).

Some previous studies have already proposed that the Holocene centennial climate variability in the western Mediterranean Sea could be linked to the North Atlantic Oscillation (NAO) variability (Jalut et al., 1997, 2000; Combourieu Nebout et al., 2002; Goy et al., 2003; Roberts et al., 2012; Fletcher et al., 2012). In particular, nine Holocene episodes of enhanced deep water convection in the Gulf of Lion (GoL) and surface cooling conditions have been described in the region (Frigola et al., 2007). These events have also been correlated to intensified upwelling conditions in the Alboran Sea and tentatively described as two-phase scenarios driven by distinctive NAO states (Ausín et al., 2015).

A growing number of studies have revealed considerable climate fluctuations during the last $2 \mathrm{kyr}$ (Abrantes et al., 2005; González-Álvarez et al., 2005; Holzhauser et al., 2005; Kaufman et al., 2009; Lebreiro et al., 2006; Martín-Puertas et al., 2008; Pena et al., 2010; Kobashi et al., 2011; NietoMoreno et al., 2011, 2013; Moreno et al., 2012; PAGES 2K Consortium, 2013; Esper et al., 2014; McGregor et al., 2015). However, there is no agreement on the exact time span of the different climatic periods defined, such as the Medieval Climatic Anomaly (MCA), a term coined originally by Stine (1994).

The existing Mediterranean climatic records for the last 1 or $2 \mathrm{kyr}$ are mostly based on terrestrial archives such as tree rings (Touchan et al., 2005, 2007; Griggs et al., 2007; Esper et al., 2007; Büntgen et al., 2011; Morellón et al., 2012), speleothem records (Frisia et al., 2003; Mangini et al., 2005; Fleitmann et al., 2009; Martín-Chivelet et al., 2011; Wassenburg et al., 2013), or lake reconstructions (Pla and Catalan, 2005; Martín-Puertas et al., 2008; Corella et al., 2011; Morellón et al., 2012). All of these archives can be good sensors of temperature and humidity changes, but it is often difficult to disentangle the effect of both variables in the proxy records. Recent efforts focussed on integrating these $2 \mathrm{kyr}$ records into regional climatic signals reveal complex regional responses and evidence the scarcity of marine records to form a more complete picture (PAGES, 2009; Lionello, 2012).

Marine records are often limited by the lack of adequate time resolution and/or robust chronologies for detailed comparison with terrestrial records. However, marine records provide a wider range of temperature-sensitive proxies. There are few marine palaeoclimate records available for the last $2 \mathrm{kyr}$ in the Mediterranean Sea (Schilman et al., 2001; Versteegh et al., 2007; Piva et al., 2008; Taricco et al., 2009, 2015; Incarbona et al., 2010; Fanget et al., 2013; Grauel et al., 2013; Lirer et al., 2013, 2014; Di Bella et al., 2014; Goudeau et al., 2015) and they are even more scarce in the western basin. Unfortunately, the existing pool of marine proxy data in the Mediterranean for the last two millennia is too sparse to recognize common patterns of climate variability (Taricco et al., 2009; Nieto-Moreno et al., 2011; Moreno et al., 2012, and references therein).

The aim of the present study is to characterize changes in surface water properties from the Minorca margin in the Catalan-Balearic Sea (central-western Mediterranean) in order to contribute to a better understanding of the climate variations in this region during the last $2.7 \mathrm{kyr}$. Sea surface temperature (SST) has been reconstructed by means of two independent proxies, $\mathrm{Mg} / \mathrm{Ca}$ analyses on the planktonic foraminifera Globigerina bulloides and alkenone-derived SST (Villanueva et al., 1997; Lea et al., 1999; Barker et al., 2005; Conte et al., 2006). The application of G. bulloides $\mathrm{Mg} / \mathrm{Ca}$ as a palaeothermometer in the western Mediterranean Sea is tested through the analysis of a series of core-top samples from different locations of the western Mediterranean Sea and the calibration reviewed consistently. $\mathrm{Mg} / \mathrm{Ca}$ thermometry is applied in conjunction with $\delta^{18} \mathrm{O}$ in order to evaluate changes in the evaporation-precipitation (E-P) balance of the basin, which are ultimately linked to salinity (Lea et al., 1999; Pierre, 1999; Barker et al., 2005).

One of the intrinsic limitations of studying the climate evolution of the last $2 \mathrm{kyr}$ is that the magnitude of climatic oscillations is often below the sensitivity of the selected proxies. In order to overcome this limitation we have produced "stack" proxy records from multicores in the same region. The stack record captures the first-order climatic variability from the proxy records and removes the noise, therefore allowing for a more robust identification of regional climatic variability.

The studied time periods have been defined as follows (years expressed as BCE, before common era, and CE, common era): the Talaiotic Period (TP, ending in $123 \mathrm{BCE}$ ), Roman Period (RP, from 123 BCE to 470 CE), "Dark Middle Ages" (DMA; from 470 until $900 \mathrm{CE}$ ), Medieval Climate Anomaly (MCA, from 900 to $1275 \mathrm{CE}$ ), and Little Ice Age (LIA, from 1275 to $1850 \mathrm{CE}$ ), with the Industrial Era (IE) as the most recent period. The limits of these periods are not uniform across the Mediterranean (Lionello, 2012), and here the selected ages have been chosen according to historical 

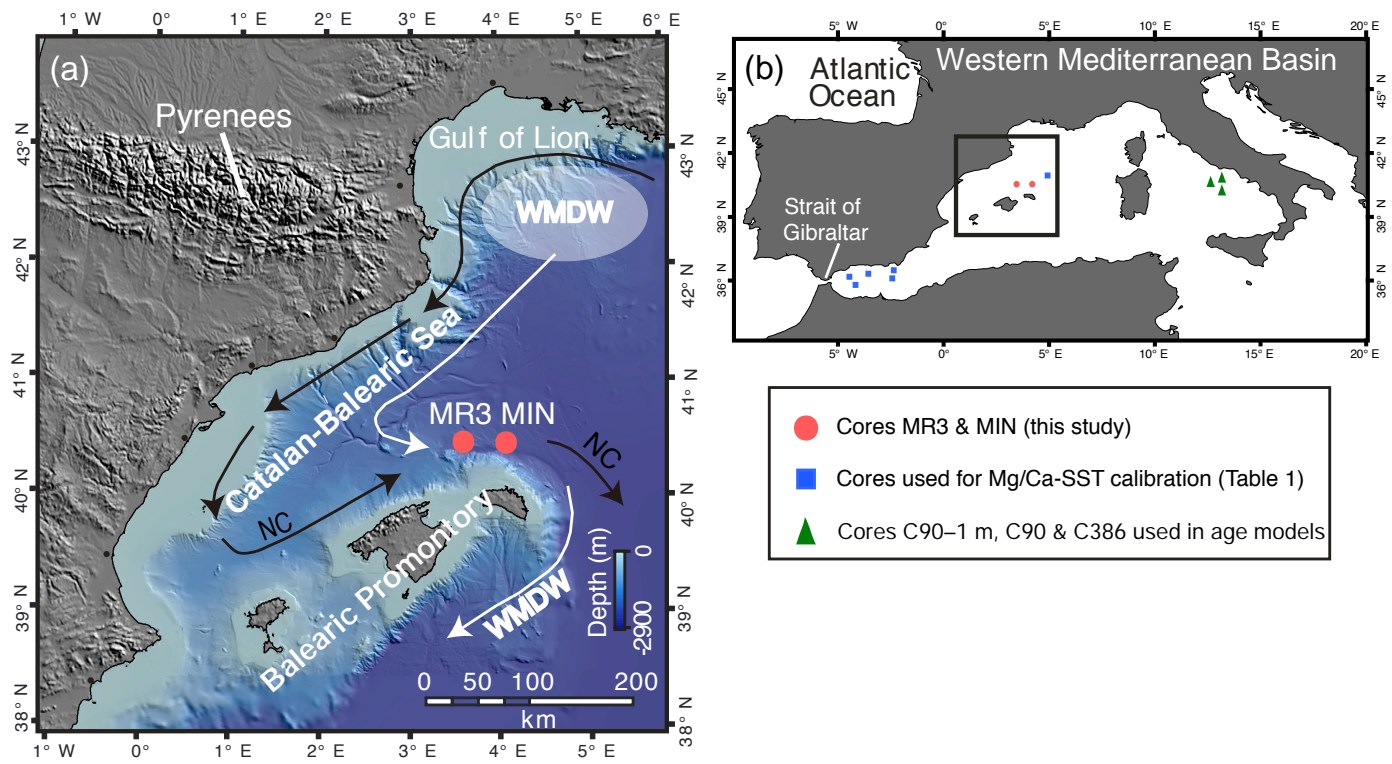

Figure 1. Location of the studied area. (a) Central-western Mediterranean Sea: cores MIN and MR3 (red dots). NC: Northern Current (surface). WMDW: Western Mediterranean Deep Water. (b) Cores used in age model development from the Tyrrhenian Sea (green triangles; Lirer et al., 2013) and cores used in Mg / Ca-SST calibration from the western Mediterranean Basin (blue squares).

events in Minorca and to the classic climatic ones defined in the literature (i.e. Nieto-Moreno et al., 2011, 2013; Moreno et al., 2012; Lirer et al., 2013, 2014).

\section{Climatic and oceanographic settings}

The Mediterranean Sea is a semi-enclosed basin located in a transitional zone between different climate regimes, from the temperate zone in the north to the subtropical zone in the south. Consequently, the Mediterranean climate is characterized by mild wet winters and warm to hot, dry summers (Lionello et al., 2006). Interannual climate variability is very much controlled by the dipole-like pressure gradient between the Azores (high) and Iceland (low) system, known as the North Atlantic Oscillation (NAO; Hurrell, 1995; Lionello and Sanna, 2005; Mariotti, 2011; Ausín et al., 2015). However, the northern part of the Mediterranean region is also linked to other mid-latitude teleconnection patterns ( $\mathrm{Li}-$ onello, 2012).

The Mediterranean Sea is a concentration basin (Béthoux, 1980; Lacombe et al., 1981) and the excess of evaporation with respect to freshwater input is balanced by water exchange at the Strait of Gibraltar (i.e. Pinardi and Masetti, 2000; Malanotte-Rizzoli et al., 2014). The basin-wide circulation pattern is predominantly cyclonic (Millot, 1999). Three convection cells promote the Mediterranean deep and intermediate circulation: a basin-wide open cell and two separated closed cells, one for the western part of the basin and one for the eastern part. The first one connects the two basins of the Mediterranean Sea though the Strait of Sicily, where water masses interchange occurs at intermediate depths. This cell is associated with the inflow of Atlantic Water (AW) at the Strait of Gibraltar and the outflow of the Levantine Intermediate Water (LIW) that flows below the first (Lionello et al., 2006).

In the north-western Mediterranean Sea, the Northern Current $(\mathrm{NC})$ represents the main feature of the surface circulation transporting waters alongshore from the Ligurian Sea to the Alboran Sea (Fig. 1a). North-east of the Balearic Promontory a surface oceanographic front separates Mediterranean waters transported by the $\mathrm{NC}$ from the Atlantic waters that recently entered the Mediterranean (Millot, 1999; Pinot et al., 2002; André et al., 2005).

Deep convection occurs offshore of the GoL due to the action of persistent cold and dry winter winds such as the tramontana and the mistral. These winds cause strong evaporation and cooling of surface water, thus increasing their density, sinking to greater depths and leading to Western Mediterranean Deep Water formation (WMDW; MEDOC, 1970; Lacombe et al., 1985; Millot, 1999). Dense shelf water cascading (DSWC) in the GoL also contributes to the sink of large volumes of water and sediments into the deep basin (Canals et al., 2006).

The north-western Mediterranean primary production is subject to an intense bloom in late winter-spring, when the surface layer stabilizes, and sometimes to a less intense bloom in autumn, when the strong summer thermocline is progressively eroded (Estrada et al., 1985; Bosc et al., 2004; D’Ortenzio and Ribera, 2009; Siokou-Frangou et al., 2010). SST in the region evolves accordingly with the seasonal bloom, with minima SST in February, which subsequently 
increases until maximum SST values during August. Afterwards, a SST drop can be observed in October, although with some interannual variability (Pastor, 2012).

\section{Material and methods}

\subsection{Sediment core description}

The studied sediment cores were recovered from a sediment drift built by the action of the southward branch of the WMDW north of Minorca (Fig. 1). Previous studies carried out at this site have already described high sedimentation rates (> $20 \mathrm{~cm} \mathrm{kyr}^{-1}$; Frigola et al., 2007, 2008; Moreno et al., 2012), suggesting that this location was suitable for a detailed study of the last millennia. The cores were recovered with a multicore system in two different stations located at about $50 \mathrm{~km}$ north of Minorca. Cores MINMC061 and MINMC06-2 (henceforth MIN1 and MIN2; 40 $29^{\prime} \mathrm{N}$, $04^{\circ} 01^{\prime} \mathrm{E}$; $2391 \mathrm{~m}$ water depth; 31 and $32.5 \mathrm{~cm}$ core length, respectively) were retrieved in 2006 during the HERMES 3 cruise onboard the R/V Thethys II. The recovery of cores HER-MC-MR3.1, HER-MC-MR3.2, and HER-MC-MR3.3 (henceforth MR3.1, MR3.2, and MR3.3; 40 $29^{\prime} \mathrm{N}, 3^{\circ} 37^{\prime} \mathrm{E}$; $2117 \mathrm{~m}$ water depth; 27,18 , and $27 \mathrm{~cm}$ core length, respectively) took place in 2009 during the HERMESIONE expedition onboard the R/V Hespérides. The distance between MIN and MR 3 cores is $\sim 30 \mathrm{~km}$ and both stations are located at an intermediate position within the sediment drift, which extends along a water depth range from 2000 to $2700 \mathrm{~m}$ (Frigola, 2012; Velasco et al., 1996; Mauffret, 1979). The MIN cores are from sites that are about $300 \mathrm{~m}$ deeper than the MR3 ones.

MIN cores were homogeneously sampled at $0.5 \mathrm{~cm}$ resolution in the laboratory. In the MR3 cores a different strategy was followed. MR3.1 and MR3.2 were initially subsampled with a PVC tube and split into two halves for X-ray fluorescence (XRF) analyses in the laboratory. Both halves of core MR3.1 (MR3.1A and MR3.1B) were used for the present work as replicates of the same core, and records for each half are shown separately. All MR3 cores were sampled at $0.5 \mathrm{~cm}$ resolution in the upper $15 \mathrm{~cm}$ and at $1 \mathrm{~cm}$ in the deeper sections, with the exception of MR3.1B that was sampled at $0.25 \mathrm{~cm}$ resolution. The MR3 cores were composed of brown-orange nannofossil and foraminifera silty clay, which was lightly bioturbated and contained layers enriched in pteropods and fragments of gastropods as well as some dark layers.

Additionally, core-top samples from seven multicores collected at different locations in the western Mediterranean have also been used for the correction of the $\mathrm{Mg} / \mathrm{Ca}-\mathrm{SST}$ calibration from G. bulloides (Table 1; Fig. 1).

\subsection{Radiocarbon analyses}

Twelve ${ }^{14} \mathrm{C}$ AMS dates were measured in cores MIN1, MIN2, and MR3.3 (Supplement Table S1) using 4-22 mg samples of the planktonic foraminifer Globorotalia inflata handpicked from the $>355 \mu \mathrm{m}$ fraction. The ages were calibrated with the standard marine correction of 408 years and the regional average marine reservoir correction $(\Delta R)$ for the central-western Mediterranean Sea using Calib 7.0 software (Stuiver and Reimer, 1993) and the MARINE13 calibration curve (Reimer et al., 2013).

\subsection{Radionuclides ${ }^{210} \mathrm{~Pb}$ and ${ }^{137} \mathrm{Cs}$}

The concentrations of the naturally occurring radionuclide ${ }^{210} \mathrm{~Pb}$ (Supplement Fig. S1) were determined in cores MIN1, MIN2, MR3.1A, and MR3.2 by alpha spectroscopy (Sanchez-Cabeza et al., 1998). The concentrations of the anthropogenic radionuclide ${ }^{137} \mathrm{Cs}$ in core MIN1 (Fig. S1) were measured by gamma spectrometry using a high-purity intrinsic germanium detector. The ${ }^{226} \mathrm{Ra}$ concentrations were determined from the gamma emissions of ${ }^{214} \mathrm{~Pb}$ that were also used to calculate the excess ${ }^{210} \mathrm{~Pb}$ concentrations. The sediment accumulation rates for the last century (Sect. S1.1 in the Supplement) were calculated using the CIC (constant initial concentration) and the CF: CS (constant flux : constant sedimentation) models (Appleby and Oldfield, 1992; Krishnaswami et al., 1971), constrained by the ${ }^{137} \mathrm{Cs}$ concentration profile in core MIN1 (Masqué et al., 2003).

\subsection{Bulk geochemical analyses}

The elemental composition of cores MR3.1B and MR3.2 was obtained with an Avaatech XRF core-scanner system (CORELAB, University of Barcelona), which is equipped with an optical variable system that allows determining the length $(10-0.1 \mathrm{~mm})$ and the extent $(15-2 \mathrm{~mm})$ of the bundle of X-rays in an independent way. This method allows obtaining qualitative information of the elementary composition of the core materials. The core surfaces were scraped, cleaned, and covered with a $4 \mu \mathrm{m}$ thin SPEXCertiPrep Ultralene foil to prevent contamination and minimize desiccation (Richter and van der Gaast, 2006). Sampling was performed every $1 \mathrm{~cm}$ and scanning took place at the split core surface directly. Among the several elements measured in this study, the Mn profile was used for the construction of the age models (see Supplement for age model development).

\subsection{Planktonic foraminiferal analyses}

Planktonic foraminifera specimens of Globigerina bulloides were picked together from a size range of $250-355 \mu \mathrm{m}$, crushed, and cleaned separately for $\mathrm{Mg} / \mathrm{Ca}$ and $\delta^{18} \mathrm{O}$ measurements. In core MR3.1B, picking was often performed in the $<355 \mu \mathrm{m}$ fraction due to the small amount of material 
Table 1. Core tops included in the calibration's adjustment. $\delta^{18} \mathrm{O}_{\mathrm{c}}$ and $\mathrm{Mg} / \mathrm{Ca}$ have been obtained from G. bulloides (Mg / Ca procedure has been performed without reductive step).

\begin{tabular}{llllcc}
\hline Core & Location & Latitude & Longitude & $\begin{array}{c}\mathrm{Mg} / \mathrm{Ca} \\
\left(\mathrm{mmol} \mathrm{mol}^{-1}\right)\end{array}$ & $\begin{array}{c}\delta^{18} \mathrm{O}_{\mathrm{c}} \\
(\% \circ \mathrm{VPDB})\end{array}$ \\
\hline TR4-157 & Balearic Abyssal Plain & $40^{\circ} 30.00^{\prime} \mathrm{N}$ & $4^{\circ} 55.76^{\prime} \mathrm{E}$ & 3.36 & 0.53 \\
ALB1 & Alboran Sea (W. Med.) & $36^{\circ} 14.31^{\prime} \mathrm{N}$ & $4^{\circ} 15.52^{\prime} \mathrm{W}$ & 3.20 & 0.80 \\
ALBT1 & Alboran Sea (W. Med.) & $36^{\circ} 22.05^{\prime} \mathrm{N}$ & $4^{\circ} 18.14^{\prime} \mathrm{W}$ & 3.44 & 0.65 \\
ALBT2 & Alboran Sea (E. Med.) & $36^{\circ} 06.09^{\prime} \mathrm{N}$ & $3^{\circ} 02.41^{\prime} \mathrm{W}$ & 3.63 & 0.57 \\
ALBT4 & Alboran Sea (E. Med.) & $36^{\circ} 39.63^{\prime} \mathrm{N}$ & $1^{\circ} 32.35^{\prime} \mathrm{W}$ & 3.72 & 0.93 \\
ALBT5 & Alboran Sea (E. Med.) & $36^{\circ} 13.60^{\prime} \mathrm{N}$ & $1^{\circ} 35.97^{\prime} \mathrm{W}$ & 3.38 & 0.64 \\
\hline
\end{tabular}

(sampling every $0.25 \mathrm{~cm}$ ). Additionally, quantitative analysis of planktonic foraminiferal assemblages was carried out in core MR3.3 and on the upper part of core MR3.1A by using the fraction size above $125 \mu \mathrm{m}$ (Fig. S2). The 42 studied samples showed abundant and well-preserved planktonic foraminifera.

The samples for trace elements analyses consisted of $\sim 45$ specimens of $G$. bulloides that were crushed under glass slides to open the chambers. Foraminifera cleaning consisted of clay removal and oxidative and weak acid leaching steps (Pena et al., 2005). Samples from core MR3.1A were also cleaned including the "reductive step". Elemental ratios were measured on an inductively coupled plasma mass spectrometer (ICP-MS, Perkin Elmer ELAN 6000) in the Scientific and Technological Centers of the University of Barcelona (CCiTUB). A standard solution with known elemental ratios was used for sample standard bracketing (SSB) as a correction for instrumental drift. The average reproducibility of $\mathrm{Mg} / \mathrm{Ca}$ ratios, taking into account the known standard solutions concentrations, was 97 and $89 \%$ for MIN1 and MIN2 cores, and 99 and $97 \%$ for cores MR3.1A, MR3.1B, and MR3.3, respectively.

Procedural blanks were routinely measured to detect any potential contamination problem during cleaning and dissolution. The $\mathrm{Mn} / \mathrm{Ca}$ and $\mathrm{Al} / \mathrm{Ca}$ ratios were also always measured to identify potential contaminations due to the presence of manganese oxides and/or aluminosilicates (Barker et al., 2003; Lea et al., 2005; Pena et al., 2005, 2008).

To avoid the overestimation of $\mathrm{Mg} / \mathrm{Ca}-\mathrm{SST}$ by diagenetic contamination, $\mathrm{Mn} / \mathrm{Ca}$ values $>0.5 \mathrm{mmol} \mathrm{mol}^{-1}$ were discarded from core MR3.1B and only those higher than $1 \mathrm{mmol} \mathrm{mol}^{-1}$ were removed from MIN1 and MR3.3. Samples suspected to have detrital contamination with elevated $\mathrm{Al} / \mathrm{Ca}$ ratios were also removed. No significant correlation exists between $\mathrm{Mg} / \mathrm{Ca}$ and $\mathrm{Mn} / \mathrm{Ca}$ or $\mathrm{Al} / \mathrm{Ca}$ ratios after data filtering $(r<0.29, p$ value $=0.06)$.

The $\mathrm{Mg} / \mathrm{Ca}$ ratios were transferred into SST values using the calibration proposed in the present study (Sect. 5.1). In the case of the MR3.1A record, which was cleaned using the reductive procedure, and as was expected (Barker et al., 2003; Pena et al., 2005; Yu et al., 2007), the Mg/ Ca ratios were about $23 \%$ lower than those measured in core MR3.1B without the reductive step. The obtained percentage of $\mathrm{Mg} / \mathrm{Ca}$ lowering is comparable to or higher than those percentages previously estimated for different planktonic foraminifera, although data from $G$. bulloides have not been previously reported (Barker et al., 2003). $\mathrm{Mg} / \mathrm{Ca}-\mathrm{SST}$ in core MR3.1A was calculated after the $\mathrm{Mg} / \mathrm{Ca}$ correction of this $23 \%$ offset by application of the calibration used with the other records.

Stable isotope measurements were performed by means of sonication on 10 specimens of $G$. bulloides after methanol cleaning to remove fine-grained particles. The analyses were performed in a Finnigan MAT 252 mass spectrometer fitted with a Kiel-IV carbonate microsampler in the CCiT-UB. The analytical precision of laboratory standards for $\delta^{18} \mathrm{O}$ was better than $0.08 \%$. Calibration to Vienna Pee Dee Belemnite (VPDB) was carried out by means of NBS-19 standards (Coplen, 1996).

Seawater $\delta^{18} \mathrm{O}\left(\delta^{18} \mathrm{O}_{\mathrm{sw}}\right)$ was obtained after removing the temperature effect on the G. bulloides $\delta^{18} \mathrm{O}$ signal using the $\mathrm{Mg} / \mathrm{Ca}-\mathrm{SST}$ records of the Shackleton palaeotemperature equation (Shackleton, 1974). The results are expressed in the SMOW (Standard Mean Ocean Water) water standard $\left(\delta^{18} \mathrm{O}_{\mathrm{sw}}\right)$ after the correction of Craig (1965). The use of specific temperature equations for G. bulloides was also considered (Bemis et al., 1998; Mulitza et al., 2003), but the core-top estimates provided $\delta^{18} \mathrm{O}_{\mathrm{sw}}$ values of $2.1-1.5 \%$ o SMOW, which were significantly higher than those measured in water samples from the central-western Mediterranean Sea ( $\sim 1.2 \%$ o SMOW) (Pierre, 1999). After application of the empirical Shackleton (1974) palaeotemperature equation, the core-top $\delta^{18} \mathrm{O}_{\mathrm{sw}}$ estimates averaged $1.1 \%$ SMOW and were closer to the actual seawater measurements. This, it was decided that this equation provided more realistic oceanographical conditions in this location.

\subsection{Alkenones}

Measurements of the relative proportion of unsaturated $\mathrm{C}_{37}$ alkenones, namely the $\mathrm{U}_{37}^{k^{\prime}}$ index, were carried out in order to obtain SST records for the studied cores. Detailed in- 
formation about the methodology and equipment used can be found in Villanueva et al. (1997). The precision of this palaeothermometry tool has been determined to be about $\pm 0.5^{\circ} \mathrm{C}$ (Eglinton et al., 2001). Furthermore, taking into account duplicate alkenone analysis carried out on core MR3.3, the precision achieved results better than $\pm 0.8^{\circ} \mathrm{C}$. The reconstruction of SST records was based on the global calibration of Conte et al. (2006), which considers an estimation standard error of $1.1^{\circ} \mathrm{C}$ in surface sediments.

\section{Age model development}

Obtaining accurate chronologies for each of the studied sediment cores is particularly critical to allow intercomparison and produce a stack record that represents the regional climatic signal. With this objective, a wide set of parameters have been combined in order to obtain chronological markers in all the studied sedimentary records, including absolute dates and stratigraphical markers based on both geochemical and micro-palaeontological data (Tables S2 and S4). The methodology of age model development is explained in detail in the Supplement.

\section{Sea surface temperatures and $\delta^{18} O$ data}

\subsection{Mg/Ca-SST calibration}

The $\mathrm{Mg}$ / Ca ratio measured in G. bulloides is a widely used proxy to reconstruct SST (Barker et al., 2005), although the calibrations available can provide very different results (Lea et al., 1999; Mashiotta et al., 1999; Elderfield and Ganssen, 2000; Anand et al., 2003; McConnell and Thunell, 2005; Cléroux et al., 2008; Thornalley et al., 2009; Patton et al., 2011). Apparently, the regional Mg / Ca-temperature response varies due to parameters that have not yet been identified (Patton et al., 2011). A further difficulty arises from the questioned $\mathrm{Mg} / \mathrm{Ca}$ thermal signal in high-salinity regions such as the Mediterranean Sea, where anomalously high $\mathrm{Mg} / \mathrm{Ca}$ values have been observed (Ferguson et al., 2008). This apparent high salinity sensitivity in foraminiferal $\mathrm{Mg} / \mathrm{Ca}$ ratios is under discussion and has not been supported by recent culture experiments (Hönisch et al., 2013), which, in addition, could be attributed to diagenetic overprints (Hoogakker et al., 2009; van Raden et al., 2011). In order to test the value of the $\mathrm{Mg}$ / Ca ratios in G. bulloides from the western Mediterranean Sea and also review its significance in terms of seasonality and depth habitat, a set of coretop samples from different locations of the western Mediterranean Sea have been analysed. Core-top samples were recovered using a multicorer system, and they can be considered representative of present conditions (Masqué et al., 2003; Cacho et al., 2006). The studied cores are located in the $35-45^{\circ} \mathrm{N}$ latitude range (Table 1 and Fig. 1) and mostly represent two different trophic regimes, defined by the clas-

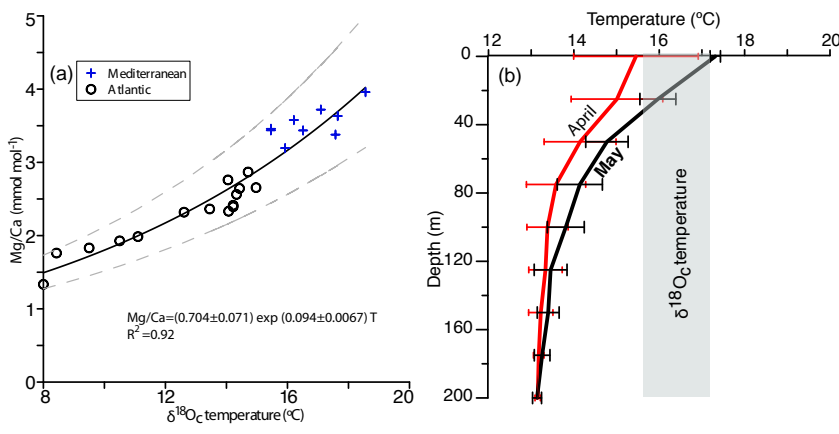

Figure 2. (a) Exponential function and correlation between $\delta^{18} \mathrm{O}_{\mathrm{c}}$ temperatures and $\mathrm{Mg} / \mathrm{Ca}$. Dashed lines show the $1 \sigma$ confidence limits of the curve fit. The standard error of our temperature calibration taking into account each $\delta^{18} \mathrm{O}_{\mathrm{c}}$ temperature from core tops (Table 1) is $\pm 0.6^{\circ} \mathrm{C}$. Error of temperature estimates based on our G. bulloides calibration for the western Mediterranean is $\pm 1.4^{\circ} \mathrm{C}$. These uncertainties are higher but still in the range of $\pm 0.6^{\circ} \mathrm{C} \mathrm{ob}$ tained for the Atlantic Ocean in Elderfield and Ganssen (2000) and also $1.1^{\circ} \mathrm{C}$ in G. bulloides culture data (Lea et al., 1999). (b) April (red) and May (black) temperature profiles of the first $200 \mathrm{~m}$ measured during years 1945-2000 in stations corresponding to the studied core tops (MEDAR GROUP, 2002). The $\delta^{18} \mathrm{O}_{\mathrm{c}}$ average temperature of all cores is shown (grey, vertical band).

sical spring bloom (the most north-western basin) and an intermittent bloom (D’Ortenzio and Ribera, 2009).

The resulting $\mathrm{Mg} / \mathrm{Ca}$ ratios have been compared with the isotopically derived calcification temperatures based on the $\delta^{18} \mathrm{O}$ measurements performed also in G. bulloides from the same samples. This comparison was performed after use of the Shackleton (1974) palaeotemperature equation and the $\delta^{18} \mathrm{O}_{\text {water }}$ data published by Pierre (1999), always considering the values of the closer stations and the top $100 \mathrm{~m}$. The resulting $\mathrm{Mg} / \mathrm{Ca}-\mathrm{SST}$ data have been plotted together with those of G. bulloides from North Atlantic core tops previously published by Elderfield and Ganssen (2000). The resulting high correlation $\left(r^{2}=0.92 ;\right.$ Fig. 2a) strongly supports that the $\mathrm{Mg} / \mathrm{Ca}$ ratios of the central-western Mediterranean Sea are dominated by a thermal signal. Thus, the new data set from the Mediterranean core tops improves temperature sensitivity range over the warm end of the calibration. The resulting exponential function indicates $\sim 9.4 \% \mathrm{Mg}$ / Ca per ${ }^{\circ} \mathrm{C}$ sensitivity in the $\mathrm{Mg}$ uptake with respect to temperature, which is in agreement with the range described in the literature (i.e., Elderfield and Ganssen, 2000; Barker et al., 2005; Patton et al., 2011). The new equation for the $\mathrm{Mg} / \mathrm{Ca}-\mathrm{SST}$ calibration including data from the western Mediterranean Sea and the Atlantic Ocean is as follows:

$\mathrm{Mg} / \mathrm{Ca}=0.7045( \pm 0.0710) e^{0.0939( \pm 0.0066) T}$.

The Mg / Ca-SST signal of G. bulloides has been compared with a compilation of water temperature profiles of the first $200 \mathrm{~m}$ measured between years 1945 and 2000 in stations close to the studied core tops (MEDAR GROUP, 2002). Al- 
though significant regional and interannual variations have been observed, the obtained calcification temperatures of our core-top samples show the best agreement with temperature values of the upper $40 \mathrm{~m}$ during the spring months (AprilMay; Fig. 2b). This water depth is consistent with preferential depth ranges for $G$. bulloides found by plankton tows in the Mediterranean (Pujol and Vergnaud-Grazzini, 1995) and with results from multiannual sediment trap monitoring in the Alboran Sea and the GoL, where maximum G. bulloides percentages were observed just before the beginning of thermal stratifications (see Bárcena et al., 2004; Bosc et al., 2004; Rigual-Hernández et al., 2012). Although the information available about depth and seasonality distribution of $G$. bulloides is relatively fragmented, this species is generally found in intermediate or even shallow waters (i.e. Bé and Hutson, 197; Ganssen and Kroon, 2000; Schiebel et al., 2002; Rogerson et al., 2004; Thornalley et al., 2009). However, G. bulloides has also been observed at deeper depths in some western Mediterranean Sea sub-basins (Pujol and VergnaudGrazzini, 1995). Extended data with enhanced spatial and seasonal coverage are required in order to better characterize production, seasonality, and geographic and distribution patterns of live foraminifera such as $G$. bulloides. Nevertheless, the obtained core-top data set offers solid evidence on the seasonal character of the recorded temperature signal in the $\mathrm{Mg} / \mathrm{Ca}$ ratio.

\subsection{A regional stack for $\mathrm{Mg} / \mathrm{Ca}-\mathrm{SST}$ records}

The Mg/Ca-SST profiles obtained from our sediment records are plotted with the resulting common age model in Fig. 3. The average SST values for the last 2700 years ranged from $16.0 \pm 0.9$ to $17.8 \pm 0.8^{\circ} \mathrm{C}$ (uncertainties of average values represent $1 \sigma$; uncertainties of absolute values include analytical precision and reproducibility and also those derived from the $\mathrm{Mg} / \mathrm{Ca}-\mathrm{SST}$ calibration). SST records show the warmest sustained period during the RP, approximately between $170 \mathrm{BCE}$ and $300 \mathrm{CE}$, except in core MIN2, since this record ends at the RP-DMA transition. In addition, all the records show a generally consistent cooling trend after the RP with several centennial-scale oscillations. The maximum SST value is observed in core MR3.3 $\left(19.6 \pm 1.8^{\circ} \mathrm{C}\right)$ during the MCA (Fig. 3c) and the minimum is recorded in core MIN1 $\left(14.4 \pm 1.4{ }^{\circ} \mathrm{C}\right.$ ) during the LIA (Fig. 3e). Centennial-scale variability is predominant throughout the records. Particularly, during MCA some warm episodes reached slightly higher SST than the averaged SST maximum (i.e. $19.6 \pm 1.8^{\circ} \mathrm{C}$ at $\sim 1021 \mathrm{CE}$ ). These events were far shorter in duration compared to the RP (Fig. 3). The highest frequency of intense cold events occurred during the LIA and, in particular, the last millennium recorded the minimum average $\mathrm{Mg} / \mathrm{Ca}-\mathrm{SST}\left(15.2 \pm 0.8^{\circ} \mathrm{C}\right)$. Four of the five records show a pronounced SST drop after $1275 \mathrm{CE}$, coinciding with the onset of the LIA. Based on the different $\mathrm{Mg} / \mathrm{Ca}-\mathrm{SST}$ patterns, the LIA period has been divided into

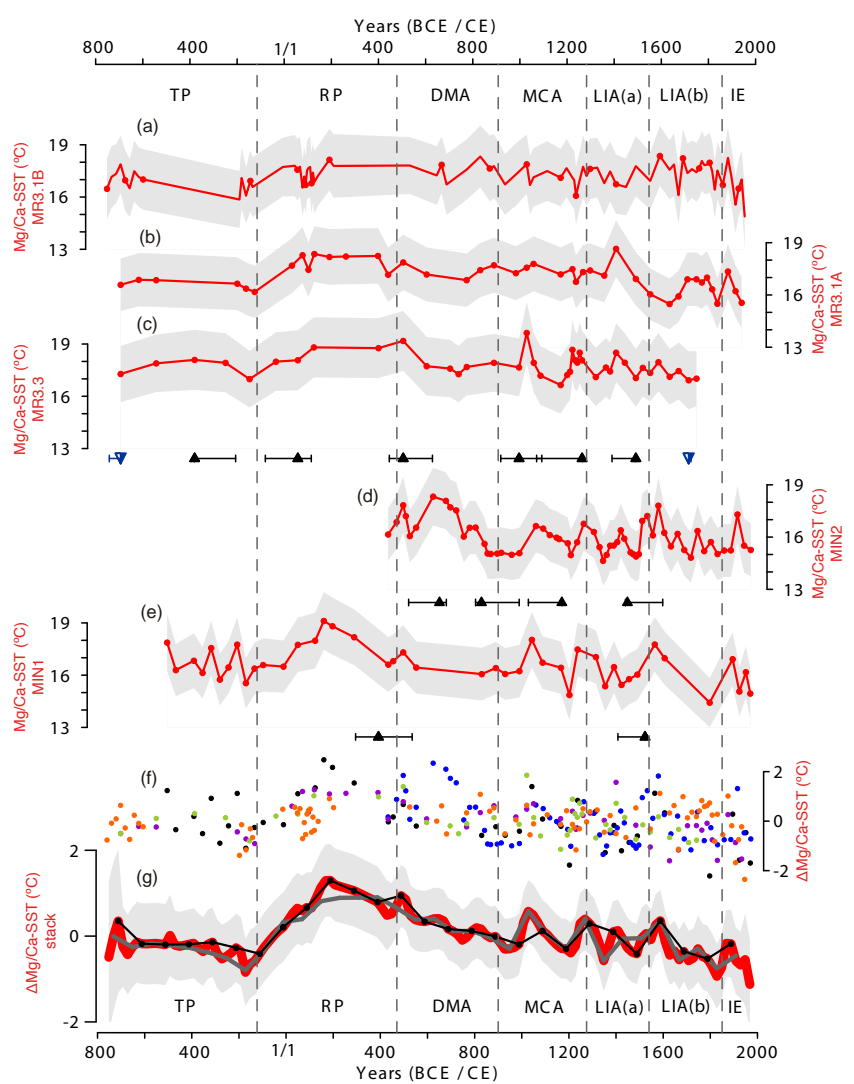

Figure 3. SST obtained from $\mathrm{Mg} / \mathrm{Ca}$ for cores: (a) MR3.1B, (b) MR3.1A, (c) MR3.3, (d) MIN2, and (e) MIN1. The grey shaded areas integrate uncertainties of average values and represent $1 \sigma$ of the absolute values. This uncertainty includes analytical precision and reproducibility and the uncertainties derived from the $G$. bulloides core-top calibrations for the centralwestern Mediterranean Sea developed in this paper. (f) All individual SST anomalies on their respective time step (MR3.1B: orange; MR3.1A: purple; MR3.3: green; MIN2: blue; MIN1: black dots). (g) $20 \mathrm{yr} \mathrm{cm}^{-1}$ stacked temperature anomaly (red plot) with its $2 \sigma$ uncertainty (grey band). The $80 \mathrm{yr} \mathrm{cm}^{-1}$ (grey plot) and the $100 \mathrm{yr} \mathrm{cm}^{-1}$ (black plot) stacks are also shown. The triangles represent ${ }^{14} \mathrm{C}$ dates (black) and biostratigraphical dates based on planktonic foraminifera (blue) and are shown below the corresponding core, including their associated $2 \sigma$ errors.

two subperiods, an early warmer interval (LIAa) and a later colder interval (LIAb) by reference to the $1540 \mathrm{CE}$ boundary.

One of the main difficulties with SST reconstructions in the last millennia is the internal noise of the records due to sampling and proxy limitations, which is of the same amplitude as the targeted climatic signal variability. In this sense, we have constructed a Mg / Ca-SST anomaly stack with the aim to detect the most robust climatic structures along the different records and reduce the individual noise. First, each SST record was converted into a SST anomaly record in relation to its average temperature (Fig. 3f). Secondly, in order to obtain a common sampling interval, all 


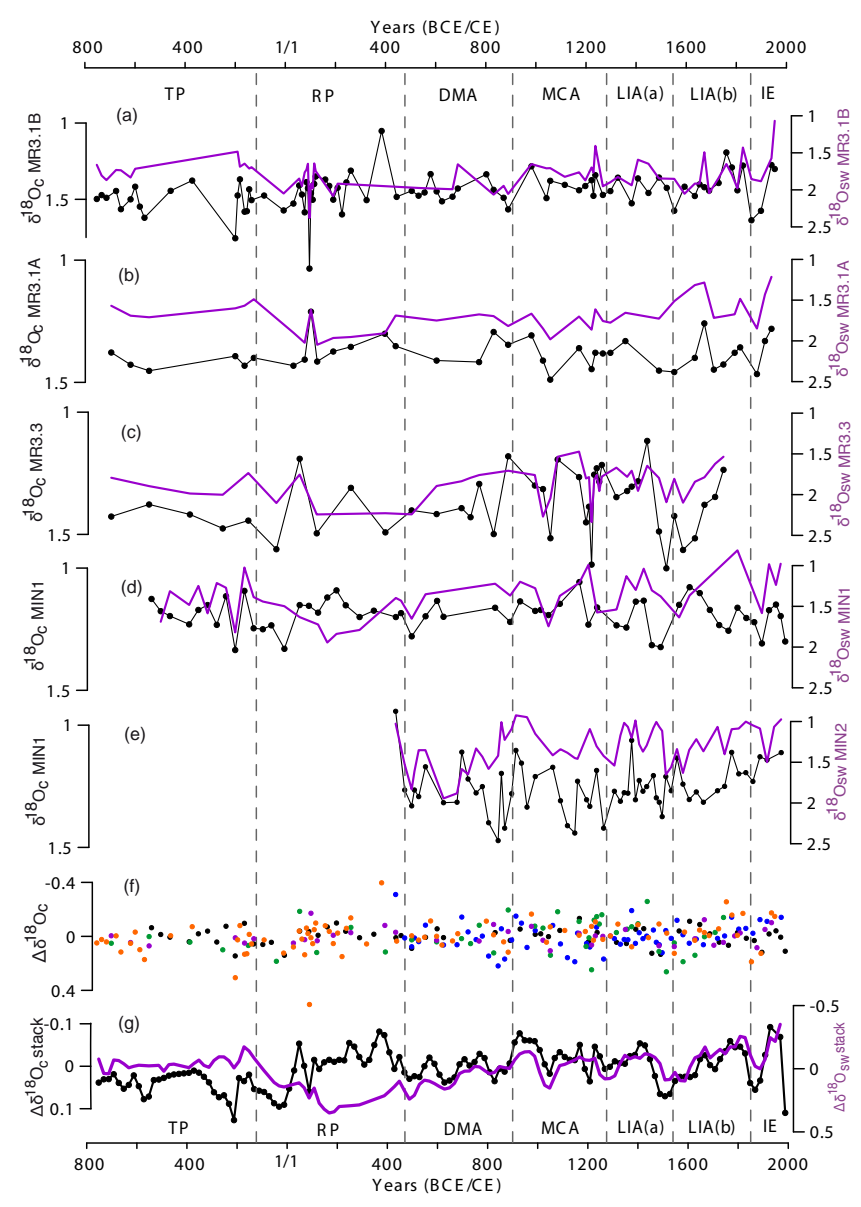

Figure 4. Oxygen isotope measured on carbonate shells of $G$. bulloides $\left(\delta^{18} \mathrm{O}_{\mathrm{c}} \%\right.$ VPDB, in black) and their derived $\delta^{18} \mathrm{O}_{\mathrm{sw}}$ (purple) for cores: (a) MR3.1B, (b) MR3.1A, (c) MR3.3, (d) MIN2, and (e) MIN1. (f) Individual $\delta^{18} \mathrm{O}_{\mathrm{c}}(\% \circ \mathrm{VPDB})$ anomalies on their respective time step. (g) $\delta^{18} \mathrm{O}_{\mathrm{c}}$ and $\delta^{18} \mathrm{O}_{\mathrm{sw}}$ anomaly stacked records (\%o VPDB and \%o SMOW, respectively).

records were interpolated. Interpolation at three different resolutions did not result in significant differences (Fig. 3g). Subsequently, we selected the stack that provided the best resolution offered by our age models $\left(20 \mathrm{yr} \mathrm{cm}^{-1}\right)$ since it very well preserves the high-frequency variability of the individual records (Fig. 3g). The obtained SST anomaly stack allows for a better identification of the most significant features at centennial timescales. Abrupt cooling events are mainly recorded during the LIA $\left(-0.5\right.$ to $\left.-0.7^{\circ} \mathrm{C} 100 \mathrm{yr}^{-1}\right)$, while abrupt warmings $\left(0.9\right.$ to $\left.0.6^{\circ} \mathrm{C} 100 \mathrm{yr}^{-1}\right)$ are detected during the MCA. Events of similar magnitude have been also documented during the LIA-IE transition. When considering the entire SST anomaly record, a long-term cooling trend of about -1 to $-2{ }^{\circ} \mathrm{C}$ is observed. However, focussing on the last 1800 years, since the RP maxima, the observed cooling trend was far more intense, at about -3.1 to $-3.5^{\circ} \mathrm{C}$ $\left(-0.3\right.$ to $\left.-0.8^{\circ} \mathrm{C} \mathrm{kyr}^{-1}\right)$. This is consistent within the recent 2 kyr global reconstruction published by McGregor et al. (2015; estimation of the SST cooling trend, using the average anomaly method 1 for the period $1-2000 \mathrm{CE}$ : -0.3 to $\left.-0.4^{\circ} \mathrm{C} \mathrm{kyr}^{-1}\right)$.

\subsection{Oxygen isotope records}

The oxygen isotopes measured on carbonate shells of $G$. bulloides $\left(\delta^{18} \mathrm{O}_{\mathrm{c}}\right)$ and their derived $\delta^{18} \mathrm{O}_{\mathrm{sw}}$ after removing the temperature effect with the $\mathrm{Mg} / \mathrm{Ca}-\mathrm{SST}$ signals (see Sect. 3.5) are shown in Fig. $4 . \delta^{18} \mathrm{O}_{\mathrm{c}}$ and their derived $\delta^{18} \mathrm{O}_{\mathrm{sw}}$ profiles have been respectively stacked following the same procedure for the $\mathrm{Mg} / \mathrm{Ca}-\mathrm{SST}$ stack (Sect. 5.2). In general terms, all the records present a highly stable pattern during the whole period with a weak depleting trend, which is almost undetectable in some cases (i.e. core MIN1).

The average $\delta^{18} \mathrm{O}_{\mathrm{c}}$ values range from 1.2 to $1.4 \%$ VPDB and, in general, the MR3 cores show slightly higher values $(\sim 1.4 \%$ o VPDB $)$ than the MIN cores $(\sim 1.2 \%$ o VPDB $)$. The lowest $\delta^{18} \mathrm{O}_{\mathrm{c}}$ values (1.0 to $1.2 \%$ VPDB) mostly occur during the RP, although some short, low excursions can also be observed during the end of the MCA and/or the LIA. The highest values (1.4 to $1.8 \%$ VPDB) are mainly associated with short events during the LIA, the MCA, and over the $\mathrm{TP}-\mathrm{RP}$ transition. A significant increase in $\delta^{18} \mathrm{O}_{\mathrm{c}}$ values is observed at the LIA-IE transition, although a sudden drop is recorded at the end of the stack record (after $1867 \mathrm{CE}$ ), which could result from a differential influence of the records (i.e. MIN1) and/or an extreme artefact (Fig. 4g).

After removing the temperature effect from the $\delta^{18} \mathrm{O}_{\mathrm{c}}$ record, the remaining $\delta^{18} \mathrm{O}_{\mathrm{sw}}$ record mainly reflects changes in E-P balance, thus resulting in an indirect proxy of sea surface salinity. The average $\delta^{18} \mathrm{O}_{\mathrm{sw}}$ values obtained for the period studied ranged from 1.3 to $1.8 \%$ SMOW. The highest $\delta^{18} \mathrm{O}_{\text {sw }}$ values (from 2.4 to $1.9 \%$ SMOW) are recorded during the RP, when the longest warm period is also observed, and some values are notable during the MCA too. Enhancements of the E-P balance $\left(\delta^{18} \mathrm{O}_{\mathrm{sw}}\right.$ higher values $)$ coincide with higher SST. The lowest $\delta^{18} \mathrm{O}_{\mathrm{sw}}$ values (from 0.8 to $1.5 \%$ SMOW) are recorded particularly during the onset and the end of the LIA and also during the MCA. A drop in the $E-P$ balance has been obtained from approximately the end of LIA to the most recent years. The most significant changes in our $\delta^{18} \mathrm{O}_{\mathrm{sw}}$ stack record correspond to increases in the most recent times and around 1200 CE (MCA) and to the decrease observed at the end of the LIA (Fig. 4).

\subsection{Alkenone-SST records}

The two alkenone $\left(\mathrm{U}_{37}^{k^{\prime}}\right)$-derived SSTs of MIN cores have already been published in Moreno et al. (2012), while the records from MR3 cores are new (Fig. 5). The four alkenoneSST records show a similar general cooling trend during the studied period and they have also been integrated in a SST anomaly stack (Fig. 5e). The general cooling trend involves about $-1.4{ }^{\circ} \mathrm{C}$ when the entire studied period is considered 


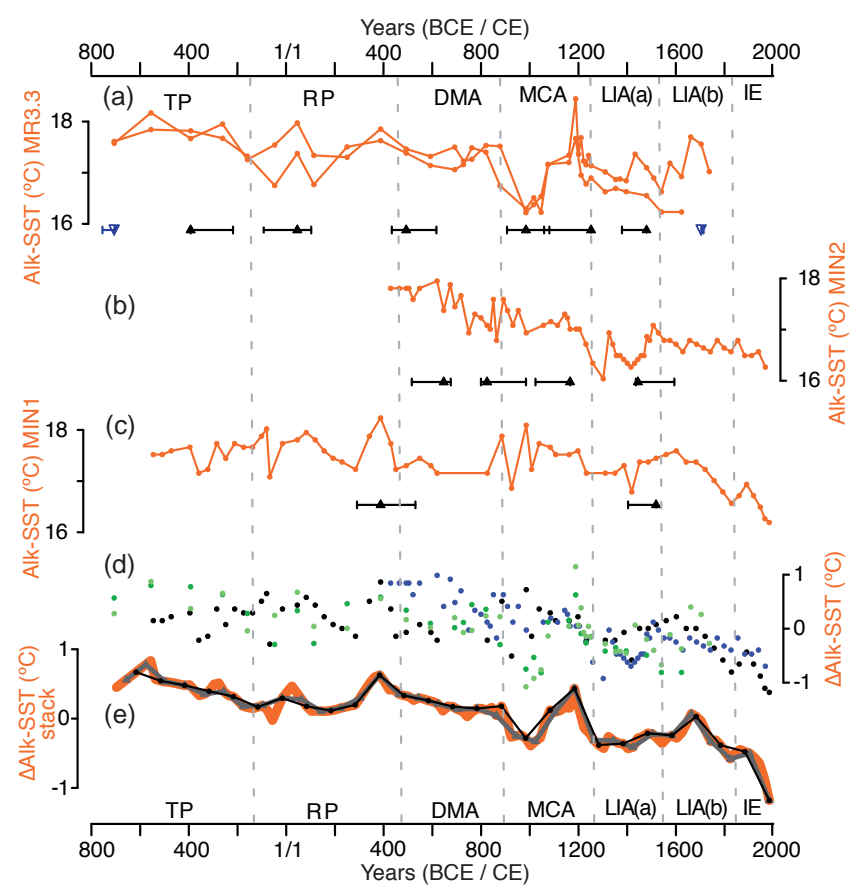

Figure 5. Alkenone temperature records from Minorca (this study) for cores (a) MR3.3, (b) MIN2, and (c) MIN1. Triangles represent ${ }^{14} \mathrm{C}$ dates (black) and biostratigraphical dates based on planktonic foraminifera (blue) and are shown below the corresponding core with their associated $2 \sigma$ errors. (d) Individual alkenonederived SST anomalies in their respective time step (MR3.3: green; MIN2: blue; MIN1: black dots). (e) $20 \mathrm{yr} \mathrm{cm}^{-1}$ stacked temperature anomaly (orange plot). The $80 \mathrm{yrcm}^{-1}$ (grey plot) and the $100 \mathrm{yr} \mathrm{cm}^{-1}$ (black plot) stacks are also shown.

and about $-1.7^{\circ} \mathrm{C}$ since the SST maximum recorded during the RP. The mean SST uncertainties in this section have been estimated as $\pm 1.1^{\circ} \mathrm{C}$, taking into account the estimated standard error (see Sect. 3.6).

Previous studies have interpreted the alkenone-SST signal in the western Mediterranean Sea as an annual average (Ternois et al., 1996; Cacho et al., 1999a, b; Martrat et al., 2004). The average alkenone-SST values for the studied period (last 2700 years) ranged from 17.0 to $17.4^{\circ} \mathrm{C}$.

The coldest alkenone temperatures $\left(\sim 16.0^{\circ} \mathrm{C}\right)$ have been obtained in core MIN2 during the LIAa and the warmest $\left(\sim 18.4^{\circ} \mathrm{C}\right)$ in core MR3.3 during the MCA. Values near the average of maxima SST (from 17.9 to $18.4^{\circ} \mathrm{C}$ ) are observed more frequently during the TP, RP, and MCA, while temperatures during the onset of MCA and LIA show many values closer to the average of minima SST (ranging from 16.0 to $16.2^{\circ} \mathrm{C}$ ). Abrupt coolings are observed during the LIA and some events during MCA $\left(-0.8^{\circ} \mathrm{C} 100 \mathrm{yr}^{-1}\right)$ and to a lesser extent during the LIA-IE transition $\left(-0.5^{\circ} \mathrm{C} 100 \mathrm{yr}^{-1}\right)$. The highest warming rates are recorded during the MCA $\left(0.4^{\circ} \mathrm{C} 100 \mathrm{yr}^{1}\right)$ and also during the RP.

\subsection{Mg / Ca-SST vs. alkenone-SST records}

In this section, the uncertainties of the alkenone, $1.1^{\circ} \mathrm{C}$, have been calculated from the estimated standard error of the calibration (see Sect. 3.6) and those of $\mathrm{Mg} / \mathrm{Ca}-\mathrm{SST}$ include the analytical precision and reproducibility and the standard error of the calibration. The measured $\mathrm{Mg} / \mathrm{Ca}-$ SST and alkenone-SST averages are identical within error $\left(16.9 \pm 1.4^{\circ} \mathrm{C}\right.$ vs. $\left.17.2 \pm 1.1^{\circ} \mathrm{C}\right)$, but the temperature range of the $\mathrm{Mg} / \mathrm{Ca}$ records shows higher amplitude (see Sects. 5.2 and 5.4).

The similarity in SST averages of both proxies does not reflect the different habitat depths, since alkenones should mirror the surface photic layer $(<50 \mathrm{~m})$, with relatively warm SST, while G. bulloides has the capability to develop in a wider and deeper environment (Bé, 1977; Pujol and Vergnaud-Grazzini, 1995; Ternois et al., 1996; Sicre et al., 1999; Ganssen and Kroon, 2000; Schiebel et al., 2002; Rogerson et al., 2004; Thornalley et al., 2009), where lower SST would be expected.

The enhanced $\mathrm{Mg} / \mathrm{Ca}-\mathrm{SST}$ variability is reflected in the short-term oscillations, at centennial timescales, which are larger in the $\mathrm{Mg} / \mathrm{Ca}$ record with oscillations over $0.5^{\circ} \mathrm{C}$. This larger $\mathrm{Mg} / \mathrm{Ca}-\mathrm{SST}$ variability could be attributed to the highly restricted seasonal character of the signal, which purely reflects SST changes during the spring season. However, the coccolith signal integrates a wider time period from autumn to spring (Rigual-Hernández et al., 2012, 2013) and, consequently, changes associated with specific seasons become more diluted in the resulting averaged signal.

The annual mean SST corresponding to a Balearic site is $18.7 \pm 1.1^{\circ} \mathrm{C}$, according to the integrated values of the upper $50 \mathrm{~m}$ (Ternois et al., 1996; Cacho et al., 1999a) of the GCCIEO database between January 1994 and July 2008. Our core-top records represent the last decades and show SST values closer to the annual mean in the case of alkenone$\mathrm{SST}$, whereas the $\mathrm{Mg} / \mathrm{Ca}-\mathrm{SST}$ record shows slightly lower values.

The $\mathrm{U}_{37}^{k^{\prime}}-\mathrm{SST}$ records in the western Mediterranean Sea have been interpreted to represent annual mean SST (i.e. Cacho et al., 1999a; Martrat et al., 2004) but seasonal variations in alkenone production could play an important role in the $\mathrm{U}_{37}^{k^{\prime}}$-SST values (Rodrigo-Gámiz et al., 2014). Considering that during the summer months the Mediterranean Sea is a very stratified and oligotrophic sea, reduced alkenone production during this season could be expected (Ternois et al., 1996; Sicre et al., 1999; Bárcena et al., 2004; Versteegh et al., 2007; Hernández-Almeida et al., 2011). This observation is supported by results from sediment traps located in the GoL showing very low coccolith fluxes during the summer months (Rigual-Hernández et al., 2013), while they exhibit higher values during autumn, winter, and spring, reaching maximum fluxes at the end of the winter season, during SST minima. In contrast, high fluxes of G. bulloides are almost restricted to the upwelling spring signal, when coccolith 
fluxes have already started to decrease (Rigual-Hernández et al., 2012, 2013). This different growth season can explain the proxy bias in the SST reconstructions, with more smoothed alkenone-SST signals.

Both $\mathrm{Mg} / \mathrm{Ca}-\mathrm{SST}$ and $\mathrm{U}_{37^{\prime}}-\mathrm{SST}$ records show consistent cooling trends of about $-0.5^{\circ} \mathrm{C} \mathrm{kyr}^{-1}$ during the studied period (2700 years), which is consistent with the recent $2 \mathrm{kyr}$ global reconstruction (McGregor et al., 2015; see Sect. 5.2). The recorded cooling since the RP SST maxima $(\sim 200 \mathrm{CE})$ is more pronounced in the $\mathrm{Mg} / \mathrm{Ca}-$ SST $\left(-1.7\right.$ to $\left.-2.0^{\circ} \mathrm{C} \mathrm{kyr}^{-1}\right)$ than in the alkenone signal $\left(-1.1^{\circ} \mathrm{C} \mathrm{kyr}^{-1}\right)$. These coolings are larger than those estimated in the global reconstruction (McGregor et al., 2015) for the last 1200 years (average anomaly method 1: -0.4 to $-0.5^{\circ} \mathrm{C} \mathrm{kyr}^{-1}$ ). It should be noted that the global reconstruction includes alkenone-SST from MIN cores (data published in Moreno et al., 2012).

The detailed comparison of the centennial SST variability recorded by both proxy stacks consistently indicates a puzzling antiphase (Fig. $6 \mathrm{~b}$ and c). Although the main trends are consistently parallel in both alkenone and $\mathrm{Mg} / \mathrm{Ca}$ proxies $(r=0.5 ; p$ value $=0)$ as observed in other regions, shortterm variability appears to have an opposite character. Statistical analysis of these differences examined by means of Welch's test indicates that the null hypothesis (means are equal) can be discarded at the $5 \%$ error level: $t_{\text {observed }}$ $(12.446)>t_{\text {critical }}(1.971)$. This a priori unexpected proxy difference outlines the relevance of the seasonal variability for climate evolution and suggests that extreme winter coolings were followed by more rapid and intense spring warmings. Nevertheless, regarding the low amplitude of several of these oscillations, often close to the proxy error, this observation needs to be supported by further constraints as a solid regional feature.

\section{Discussion}

\subsection{Climate patterns during the last $2.7 \mathrm{kyr}$}

The SST changes in the Minorca region have implications for the surface air mass temperature and moisture source regions that could influence on air mass trajectories and ultimately precipitation patterns in the western Mediterranean region (Millán et al., 2005; Labuhn et al., 2015). Recent observations have identified SST as a key factor in the development of torrential rain events in the western Mediterranean Basin (Pastor et al., 2001), constituting a potential source of mass instability that transits over these waters (Pastor, 2012). In this context, the combined SST and $\delta^{18} \mathrm{O}_{\mathrm{sw}}$ records can provide information on the connection between thermal changes and moisture export from the central-western Mediterranean Sea during the last $2.7 \mathrm{kyr}$.

The oldest period recorded in our data is the so-called Talaiotic Period (TP), which corresponds to the ages of antiquity such as the period of ancient Greece in other geo-

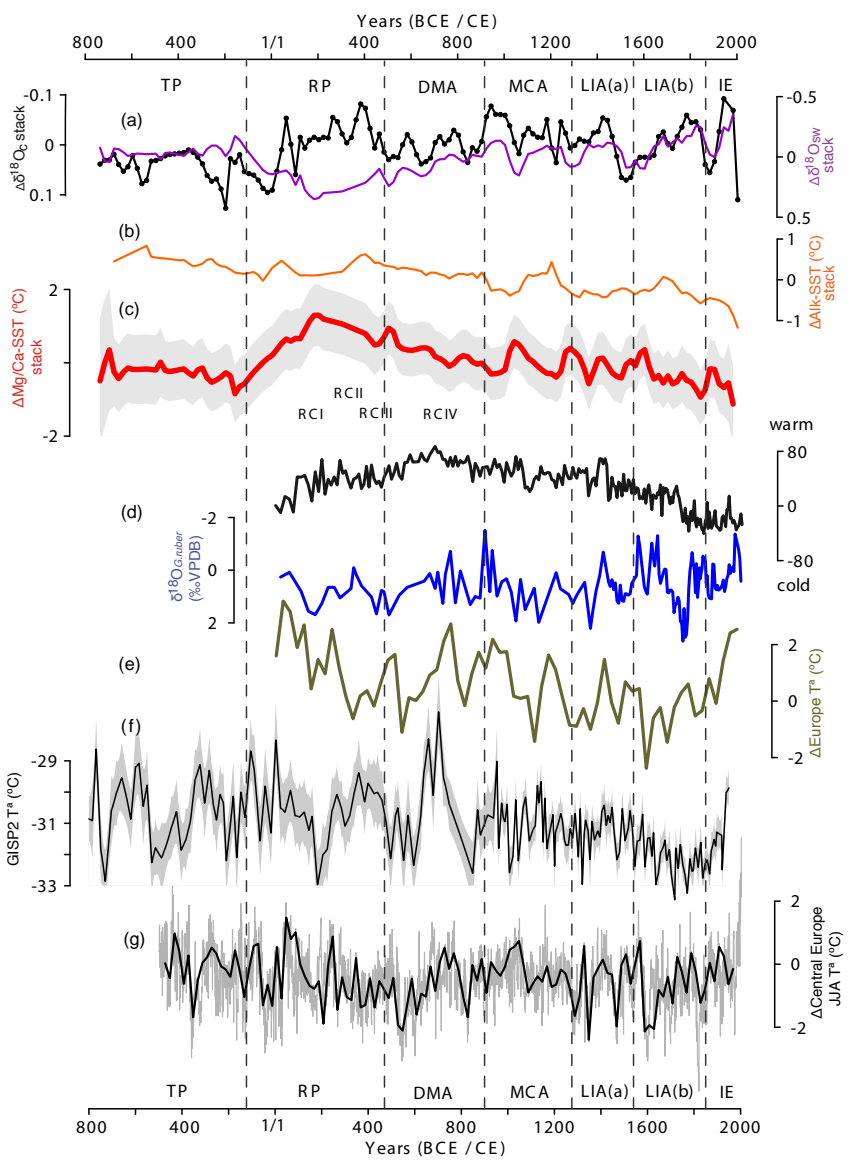

Figure 6. Temperature and isotope anomaly records from Minorca (this study) and data from other regions. (a) $\delta^{18} \mathrm{O}_{\mathrm{c}}$ and $\delta^{18} \mathrm{O}_{\mathrm{sw}}$ (\%o SMOW) Minorca stacks; (b) alkenone-SST anomaly Minorca stack; (c) Mg / Ca-SST anomaly Minorca stack; (d) warm and cold phases and $\delta^{18} \mathrm{O}_{\text {G.ruber }}$ recorded by planktonic foraminifera from the southern Tyrrhenian composite core, with RCI to RCIV showing Roman cold periods (Lirer et al., 2014); (e) 30-year averages of the PAGES 2k Network (2013) Europe anomaly temperature reconstruction; (f) Greenland snow surface temperature (Kobashi et al., 2011); and (g) central Europe summer anomaly temperature reconstruction in central Europe (Büntgen et al., 2011).

graphic areas. Both $\mathrm{Mg} / \mathrm{Ca}-\mathrm{SST}$ and alkenone-SST records are consistent in showing a general cooling trend from $\sim 500 \mathrm{BCE}$ and reaching minimum values by the end of the period $(\sim 120$ BCE; Fig. 6a-b). Very few other records are available from this time period, which make comparisons of these trends at regional scale difficult.

One of the most prominent features in the two SST reconstructions, particularly in the $\mathrm{Mg} / \mathrm{Ca}-\mathrm{SST}$ stack, is the warm SST that predominated during the second half of the RP (150-400 CE). The onset of the RP was relatively cold and a $\sim 2{ }^{\circ} \mathrm{C}$ warming occurred during the first part of this period. This SST evolution from colder to warmer conditions during the RP is consistent with the isotopic record of the Gulf of Taranto (Taricco et al., 2009) and peat recon- 
structions from north-west Spain (Martínez-Cortizas et al., 1999), and to some extent with SST proxies in the southeastern Tyrrhenian Sea (Lirer et al., 2014). However, none of these records indicates that the RP was the warmest period of the last $2 \mathrm{kyr}$. Other records from higher latitudes such as Greenland (Dahl-Jensen et al., 1998), and northern Europe (Esper et al., 2014), North Atlantic Ocean (Bond et al., 2001; Sicre et al., 2008), as well as speleothem records from northern Iberia (Martín-Chivelet et al., 2011) and even the multiproxy PAGES $2 \mathrm{~K}$ reconstruction from Europe, suggest a rather warmer early RP than late RP and, again, none of these records highlights the Roman times as the warmest climate period of the last $2 \mathrm{kyr}$. Consequently, these very warm RP conditions recorded in the Minorca Mg / Ca-SST stack seem to have a regional character and suggest that climate evolution during this period followed a rather heterogeneous thermal response along the European continent and surrounding marine regions.

Moreover, the observed $\delta^{18} \mathrm{O}_{\mathrm{sw}}$ stack of the RP suggests an increase in the E-P ratio (Fig. 6a) during this period, which has also been observed in some nearby regions like the Alps (Holzhauser et al., 2005; Joerin et al., 2006). In contrast, a lake record from southern Spain indicates relatively high water levels when the $\delta^{18} \mathrm{O}_{\mathrm{sw}}$ stack indicates the maximum in E-P ratio (Martín-Puertas et al., 2008). This information is not necessarily contradictory, since enhanced $\mathrm{E}-\mathrm{P}$ balance in the Mediterranean could be balanced out by enhanced precipitation in some of the regions, but more detailed geographical information is required to interpret these proxy records from distinct areas.

After the RP, during the whole DMA and until the MCA, the $\mathrm{Mg} / \mathrm{Ca}-\mathrm{SST}$ stack shows a cooling of $\sim 1{ }^{\circ} \mathrm{C}$ $\left(-0.2^{\circ} \mathrm{C} 100 \mathrm{yr}^{-1}\right)$, which is $0.3^{\circ} \mathrm{C}$ in the case of the alkenone-SST stack and the E-P rate decreases. This trend contrasts with the general warming trend interpreted from the speleothem records of northern Iberia (Martín-Chivelet et al., 2011) or the transition towards drier conditions observed in Alboran records (Nieto-Moreno et al., 2011). However, SST proxies from the Tyrrhenian Sea show a cooling trend after the second half of the DMA and the Roman IV cold/dry phase (Lirer et al., 2014) that can be tentatively correlated with our SST records (Fig. 6). This cooling phase is also documented in the $\delta^{18} \mathrm{O}_{G \text {.ruber }}$ record of the Gulf of Taranto (Grauel et al., 2013). These heterogeneities in the signals from the different proxies and regions illustrate the difficulties in characterizing the climate variability during these short periods and reinforce the need for a better geographical coverage of individual proxies.

The medieval period is usually described as a very warm period in numerous regions in the Northern Hemisphere (Hughes and Diaz, 1994; Mann et al., 2008; Martín-Chivelet et al., 2011), but this interpretation is challenged by an increasing number of studies (i.e. Chen et al., 2013). The Minorca SST stacks also show the occurrence of significant temperature variability that does not reflect a specific warm period within the last $2 \mathrm{kyr}$ (Fig. 6). An important warming event is observed at $\sim 1000 \mathrm{CE}$, followed by a later cooling with minimum values at about $1200 \mathrm{CE}$ (Fig. 6). Higher temperature variability is found in Greenland records (Kobashi et al., 2011), while an early warm MCA and posterior cooling is also observed in temperature reconstructions from central Europe (Büntgen et al., 2011) and in the European multiproxy 2 kyr stack of the PAGES 2K Consortium (2013). Nevertheless, all these proxies agree in indicating overall warmer temperatures during the MCA than during the LIA. At the MCA-LIA transition, a progressive cooling and a change in oscillation frequency before and after the onset of LIA are recorded. This transition is consistent with the last rapid climate change (RCC) described in Mayewski et al. (2004).

In the context of the Mediterranean Sea, the lake, marine, and speleothem records consistently agree in showing drier conditions during the MCA than during the LIA (Moreno et al., 2012; Chen et al., 2013; Nieto-Moreno et al., 2013; Wassenburg et al., 2013). Examination of the $\delta^{18}$ sw stack shows several oscillations during the MCA and LIA but no clear differentiation between these periods can be inferred from this proxy, indicating that reduced precipitation also involved reduced evaporation in the basin and that the E-P balance recorded by the $\delta^{18} \mathrm{O}_{\text {sw }}$ proxy was not modified. The centennial-scale variability found in both the $\mathrm{Mg} / \mathrm{Ca}-\mathrm{SST}$ and $\delta^{18} \mathrm{O}_{\mathrm{sw}}$ stack reveals that higher E-P conditions existed during the warmer intervals (Fig. 6a and c).

According to the Mg / Ca-SST stack, the LIA stands out as a period of high thermal variability in which two substages can be differentiated, a first involving large SST oscillations and warm average temperatures (LIAa) and a second substage with short oscillations and cold average SST (LIAb). We suggest that the LIAa interval could be linked to the Wolf and Spörer solar minima and that the LIAb corresponds to Maunder and Dalton cold events, in agreement with previous observations (i.e. Vallefuoco et al., 2012).

These two LIA substages are also present in the Greenland record (Kobashi et al., 2011). The intense cooling drop $\left(0.8^{\circ} \mathrm{C} 100 \mathrm{yr}^{-1}\right)$ at the onset of the LIAb is in agreement with the suggested coolings of 0.5 and $1{ }^{\circ} \mathrm{C}$ in the Northern Hemisphere (i.e. Matthews and Briffa, 2005; Mann et al., 2009). These two steps within the LIA are better reflected in the $\mathrm{Mg} / \mathrm{Ca}-\mathrm{SST}$ stack than in the alkenone-SST stack. This is also the case of the alkenone records in the Alboran Sea (Nieto-Moreno et al., 2011), which may result from smaller SST variability of the alkenone proxies (see Sect. 5.5).

In terms of humidity, the LIA represents a period of increased runoff in the Alboran record (Nieto-Moreno et al., 2011). Available lake level reconstructions from southern Spain also show progressive increases after the MCA, reaching maximum values during the LIAb (Martín-Puertas et al., 2008). Different records of flood events in the Iberia Peninsula also report a significant increase in extreme events during the LIA (Barriendos and Martin-Vide, 1998; Benito et al., 2003; Moreno et al., 2008). These conditions are consis- 
tent with the described enhanced storm activity over the GoL in this period (Sabatier et al., 2012), explaining the enhanced humidity transport towards the Mediterranean Sea as a consequence of the reduced E-P ratio observed in the $\delta^{18} \mathrm{O}_{\mathrm{sw}}$, particularly during the LIAb (Fig. 6a).

The end of the LIA and onset of the IE is marked with a warming phase of about $1{ }^{\circ} \mathrm{C}$ in the $\mathrm{Mg} / \mathrm{Ca}-\mathrm{SST}$ stack and a lower-intensity change in the alkenone-SST stack. This initial warm climatic event is also documented in other Mediterranean regions (Taricco et al., 2009; Marullo et al., 2011; Lirer et al., 2014) and Europe (PAGES 2K Consortium, 2013), which is coincident with a total solar irradiance (TSI) enhancement after Dalton minima. The two Minorca SST stacks show a cooling trend by the end of the record, which does not seem to be consistent with the instrumental atmospheric records. In the western Mediterranean, warming has been registered in two main phases: from the mid-1920s to 1950s and from the mid-1970s onwards (Lionello et al., 2006). The Minorca stacks do not show this warming, but they do not cover the second warming period. Nevertheless, the instrumental data from the beginning of the 20th century in the western Mediterranean do not display any warming trends before the 1980s (Vargas-Yáñez et al., 2010).

\subsection{Climate forcing mechanisms}

The general cooling trend observed in both $\mathrm{Mg} / \mathrm{Ca}-\mathrm{SST}$ and alkenone-SST stacks shows a good correlation with the evolution of summer insolation in the North Hemisphere, which dominates the present annual insolation balance ( $r=0.2$ and $0.8, p$ value $\leq 0.007$, respectively; Fig. 7). In numerous records from the Northern Hemisphere (i.e. Wright, 1994; Marchal et al., 2002; Kaufman et al., 2009; Moreno et al., 2012), this external forcing has also been proposed to control major SST trends during the Holocene period. In addition, summer insolation seems to have had significant influence in the decreasing trend of the isotope records during the whole period spanned $(r=0.4$, $p$ value $=0$ ), as has been suggested in, for example, Ausín et al. (2015). In any case, a different forcing mechanism needs to account for the centennial-scale variability of the records, e.g. increased volcanism in the last millennium (McGregor et al., 2015), although no significant correlations have been observed between our records and volcanic reconstructions (Gao et al., 2008).

Solar variability has frequently been proposed to be a primary driver of the Holocene millennial-scale variability (i.e. Bond et al., 2001). Several oscillations observed in the TSI record (Fig. 7a), but the correlations with the $\mathrm{Mg} / \mathrm{Ca}-\mathrm{SST}$ and alkenone-SST stacks are low, since most of the major TSI drops do not correspond to SST cold events. However, some correlation is observed between TSI and alkenone SSTs $(r=0.5, p$ value $=0)$. In any case, TSI does not seem to be the main driver of the centennial-scale SST variability in the studied records.

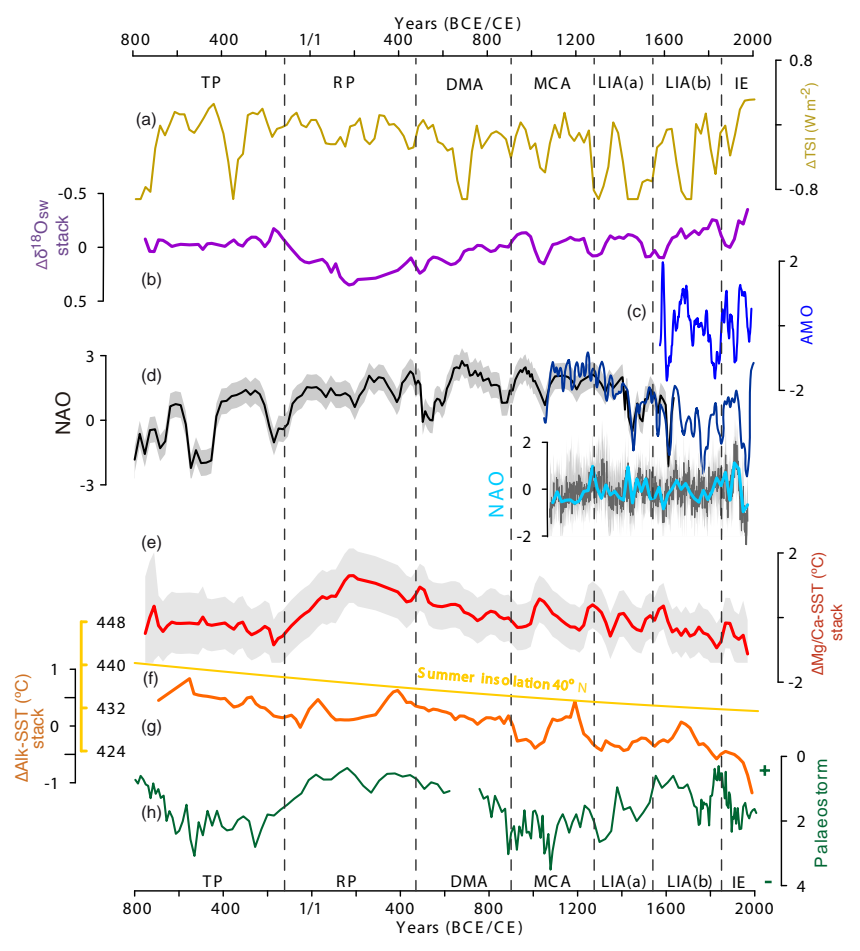

Figure 7. Temperature and isotope anomaly records from Minorca (this study) and data from other regions and with external forcings: (a) total solar irradiance (Steinhilber et al., 2009, 2012), (b) $\delta^{18} \mathrm{O}_{\mathrm{sw}}$ Minorca stacks, (c) Atlantic Multidecadal Oscillation (AMO; Gray et al., 2004), (d) North Atlantic Oscillation (NAO) reconstructions (Olsen et al., 2012; Trouet et al., 2009; and, for the last millennium, Ortega et al., 2015), (e) Mg / Ca-SST anomaly Minorca stack, (f) summer insolation at $40^{\circ} \mathrm{N}$ (Laskar et al., 2004), (g) alkenoneSST anomaly Minorca stack, and (h) palaeostorm activity in the Gulf of Lion (Sabatier et al., 2012).

One of the major drivers of the Mediterranean interannual variability in the Mediterranean region is the NAO (Hurrell, 1995; Lionello and Sanna, 2005; Mariotti, 2011). Positive NAO indexes are characterized by high atmospheric pressure over the Mediterranean Sea and increases of the E-P balance (Tsimplis and Josey, 2001). During these positive NAO periods, winds over the Mediterranean tend to be deviated towards the north, overall salinity increases, and formation of dense deep water masses is reinforced as the water exchange through the Corsica Channel is higher and the arrival of northern storm waves decreases (Wallace and Gutzler, 1981; Tsimplis and Baker, 2000; Lionello and Sanna, 2005). The effect of NAO on Mediterranean temperatures is more ambiguous. SST changes during the last decades do not show significant variability with NAO (Luterbacher et al., 2004; Mariotti, 2011), although some studies suggest an opposite response between the two basins, with cooling responses in some eastern basins and warmings in the western basin during positive NAO conditions (Demirov and Pinardi, 2002; Tsimplis and Rixen, 2002). Although still controver- 


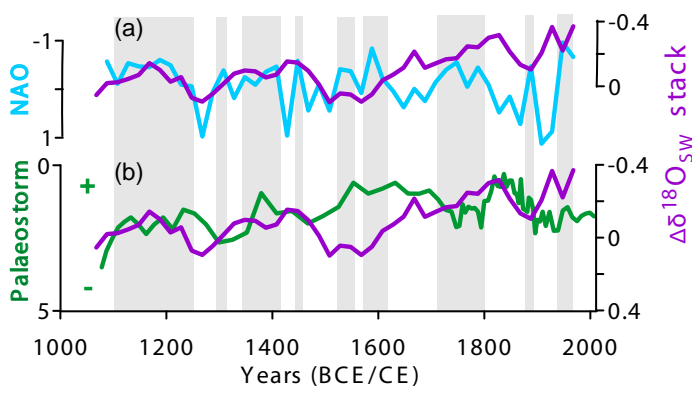

Figure 8. $\delta^{18} \mathrm{O}_{\mathrm{sw}}$ Minorca stack (\%o SMOW) during the last millennium (age is expressed in years CE) plotted with (a) NAO reconstruction (Ortega et al., 2015) and (b) palaeostorm activity in the Gulf of Lion (Sabatier et al., 2012). Notice that the NAO axis is on a descending scale. Grey vertical bars represent negative NAO phases.

sial, some NAO reconstructions on proxy records are starting to become available for the period studied (Lehner et al., 2012; Olsen et al., 2012; Trouet et al., 2012; Ortega et al., 2015). The last millennium is the best-resolved period, and it allows a direct comparison with our data to evaluate the potential link to NAO.

The correlations between our Minorca temperature stacks with NAO reconstructions (Fig. 7) are relatively low in the case of $\mathrm{Mg} / \mathrm{Ca}-\mathrm{SST}(r=0.3, p$ value $\leq 0.002)$ and not significant in the alkenone stack, indicating that this forcing is probably not the driver of the main trends in these records, although several uncertainties still exist about the long NAO reconstructions (Lehner et al., 2012). If detailed analysis is performed focussing on the more intense negative NAO phases (Fig. 7), they mostly appear to correlate with cooling phases in the $\mathrm{Mg} / \mathrm{Ca}$ stack. The frequency of these negative events is particularly high during the LIA, and mostly during its second phase (LIAb), when the coldest intervals of our SST stacks were observed.

When several different proxy last century records of annual resolution, tested with some model assimilations (Ortega et al., 2015), are compared with the last NAO reconstruction, the observed correlations with $\delta^{18} \mathrm{O}_{\mathrm{sw}}$ are not statistically significant. However, the Welch's test results do not allow for the null hypothesis to be discarded. A coherent pattern of NAO variability with our $\delta^{18} \mathrm{O}_{\mathrm{sw}}$ reconstruction, with high (low) isotopic values mainly dominating during positive (negative) NAO phases, can be observed in the last centuries (Fig. 8). This pattern is consistent with the described E-P increase during high NAO phases described for the last decades (Tsimplis and Josey, 2001). The SST stacks also suggest some degree of correlation between warm SST and high NAO values (Fig. 7), but a more coherent picture is observed when the SST records are compared to the Atlantic Meridional Oscillation (AMO) reconstruction: warm SST dominated during high AMO values (Fig. 9). This pattern of salinity changes related to NAO and SST to AMO has also been

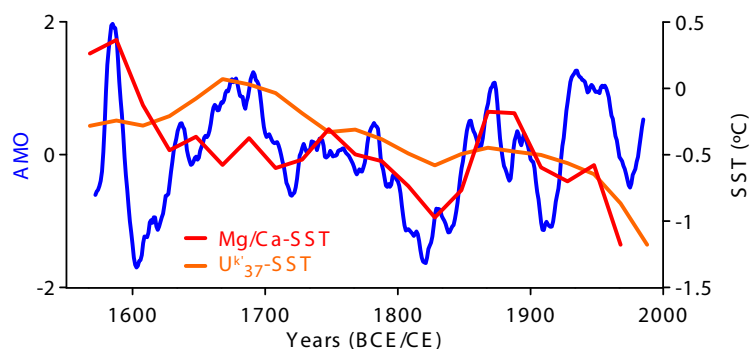

Figure 9. $\mathrm{Mg} / \mathrm{Ca}-\mathrm{SST}$ and alkenone-SST Minorca anomaly stacks during the last centuries plotted with AMO reconstruction (Gray et al., 2004).

described in climate studies encompassing the last decades (Mariotti, 2011; Guemas et al., 2014) and confirms the complex but tight response of the Mediterranean to atmospheric and marine changes over the North Atlantic Ocean.

The pattern of high $\delta^{18} \mathrm{O}_{\text {sw }}$ at dominant positive NAO corresponds to a reduction in the humidity transport over the Mediterranean region as a consequence of high atmospheric pressure (Tsimplis and Josey, 2001). Accordingly, several periods of increased/decreased storm activity in the GoL (Fig. 8; Sabatier et al., 2012) correlate with low/high values in the $\delta^{18} \mathrm{O}_{\mathrm{sw}}$, indicating that, during negative NAO conditions, northern European storm waves arrived more frequently in the Mediterranean Sea (Lionello and Sanna, 2005), contributing to the reduction of the E-P balance (Fig. 8). Our data also indicate that, during these enhanced storm periods, cold SST conditions dominated in the region as previously suggested (Sabatier et al., 2012). Nevertheless, not all the NAO oscillations had identical expression in the compared records, which is coherent with recent observations indicating that negative NAO phases may correspond to different atmospheric configuration modes and impact differently over the western Mediterranean Sea (Sáez de Cámara et al., 2015). Regarding the lower part of the record, the maximum SST temperatures and $\delta^{18} \mathrm{O}_{\mathrm{sw}}$ recorded during the RP (100-300 CE) may suggest the occurrence of persistent positive NAO conditions, which would also be consistent with a high pressure-driven drop in relative sea level as has been reconstructed in the north-western Mediterranean Sea (southern France, $-40 \pm 10 \mathrm{~cm}$; Morhange et al., 2013).

It is interesting to note that during the DMA a pronounced and intense cooling event is recorded in the $\mathrm{Mg} / \mathrm{Ca}-\mathrm{SST}$ stack at about $500 \mathrm{CE}$. Several references document in the scientific literature the occurrence of a dimming of the sun at 536-537 CE (Stothers, 1984). This event, based on ice core records, has been linked to a tropical volcanic eruption (Larsen et al., 2008). Tree-ring data reconstructions from Europe and also historical documents indicate the persistence during several years $(536-550 \mathrm{CE})$ of what is described as the most severe cooling across the Northern Hemisphere during the last two millennia (Larsen et al., 2008). Despite the limitations derived from the resolution of our records, the 
$\mathrm{Mg} / \mathrm{Ca}-\mathrm{SST}$ stack record may have caught this cooling, which would prove the robustness of our age models (see Supplement for age model development).

\section{Summary and conclusions}

The review of new core-top data of G. bulloides $\mathrm{Mg} / \mathrm{Ca}$ ratios from the central-western Mediterranean Sea together with previous published data support a consistent temperature sensitivity for the Mediterranean samples and allows for the previous calibrations to be refined. The recorded $\mathrm{Mg} / \mathrm{Ca}-\mathrm{SST}$ signal from G. bulloides is interpreted to reflect April-May conditions from the upper $40 \mathrm{~m}$ layer. In contrast, the alkenone-SST estimations are interpreted to integrate a more annually averaged signal, although they are biased toward the winter months since primary productivity during the summer months in the Mediterranean Sea is extremely low. The averaged signal of the alkenone-SST records may explain its relatively smoothed oscillations in comparison to the $\mathrm{Mg} / \mathrm{Ca}-\mathrm{SST}$ records.

After careful construction of a common chronology for the studied multicores, based on several chronological tools, the individual proxy records have been grouped in an anomalystacked record to allow a better identification of the main patterns and structures. Both $\mathrm{Mg} / \mathrm{Ca}-\mathrm{SST}$ and alkenone stacks show a consistent cooling trend over the studied period. Since the RP maximum, this cooling has ranged between -1.7 and $-2.0^{\circ} \mathrm{C} \mathrm{kyr}^{-1}$ in the $\mathrm{Mg} / \mathrm{Ca}$ record and is less pronounced in the alkenone record $\left(-1.1^{\circ} \mathrm{C} \mathrm{kyr}^{-1}\right)$. This cooling trend is consistent with the general lowering of summer insolation. The overall cooling is punctuated by several SST oscillations at centennial timescales, which represent maximum SST during most of the RP; a progressive cooling during the DMA; a pronounced variability during the MCA with two intense warming phases reaching warmer SST than during the LIA; and a very unstable and rather cold LIA, with two substages - a first one with larger SST oscillations and warmer average temperatures (LIAa) and a second one with shorter oscillations and colder average SST (LIAb). The described two stages within the LIA are clearer in the $\mathrm{Mg} / \mathrm{Ca}-\mathrm{SST}$ stack than in the alkenone-SST record. Comparison of $\mathrm{Mg} / \mathrm{Ca}-$ SST and $\delta^{18} \mathrm{O}_{\text {sw }}$ stacks indicates that warmer intervals have been accompanied by higher evaporation-precipitation (EP) conditions. The E-P balance oscillations over each defined climatic period during the last $2.7 \mathrm{kyr}$ suggest variations in the thermal change and moisture export patterns in the central-western Mediterranean.

Comparison of the Minorca SST stacks with other European palaeoclimatic records suggests a rather heterogeneous thermal response along the European continent and surrounding marine regions. Comparison of the new Mediterranean records with the reconstructed variations in TSI does not support a clear connection with this climate forcing. Nevertheless, changes in the NAO and AMO seem to have in- fluenced the regional climate variability. The negative NAO phases correlate mostly with cooling phases of the $\mathrm{Mg} / \mathrm{Ca}$ stack, although this connection is complex and apparently better defined during the most intense negative phases. Focussing on the last $1 \mathrm{kyr}$, when NAO reconstructions are better constrained, provides a more consistent pattern, with cold and particularly fresher $\delta^{18} \mathrm{O}_{\mathrm{sw}}$ values (reduced E-P balance) during negative NAO phases. Our results are consistent with enhanced southward transport of European storm tracks during this period and previous reconstructions of storm activity in the GoL. Nevertheless, the SST stacks show a more tied relation to AMO during the last four centuries (the available period of AMO reconstructions) in which warm SST dominated during high AMO values. This evidence supports a close connection between Mediterranean and North Atlantic climatology over the last $2 \mathrm{kyr}$.

\section{The Supplement related to this article is available online at doi:10.5194/cp-12-849-2016-supplement.}

Acknowledgements. Cores MINMC06 were recovered by the HERMES 3 cruise in 2006 on R/V Thethys II and HER-MC-MR3 cores were collected by the HERMESIONE expedition onboard $\mathrm{R} / \mathrm{V}$ Hespérides in 2009. This research was financially supported by OPERA (CTM2013-48639-C2-1-R) and Consolider-Redes (CTM2014-59111-REDC). We thank Generalitat de Catalunya Grups de Recerca Consolidats for grant 2009 SGR 1305 to GRC Geociències Marines. The Project of Strategic Interest NextData PNR 2011-2013 (www.nextdataproject.it) also collaborated in the financing. We are grateful to $\mathrm{M}$. Guart (Dept. de Dinàmica de la Terra i de l'Oceà, Universitat de Barcelona), M. Romero, T. Padró and J. Perona (Serveis Cientifico-Tècnics, Universitat de Barcelona), J. M. Bruach (Departament de Física, Universitat Autònoma de Barcelona), and B. Hortelano, Y. Gonzalez-Quinteiro, and I. Fernández (Institut de Diagnosi Ambiental i Estudis de l'Aigua, CSIC, Barcelona) for their help with the laboratory work; to D. Amblàs for his collaboration with the artwork of maps; and to Paleoteam for the unconditional support. E. Garcia-Solsona, S. Giralt, and M. Blaauw are acknowledged for their help. We also acknowledge the guest editor and anonymous reviewers for their comments, which contributed to improving this paper. Belen Martrat acknowledges funding from CSIC-Ramon y Cajal post-doctoral programme RYC-2013-14073. Mercè Cisneros benefited from a fellowship of the University of Barcelona. Leopoldo D. Pena acknowledges support from the Ramón y Cajal programme (MINECO, Spain). Isabel Cacho thanks the ICREA-Academia programme from the Generalitat de Catalunya.

Edited by: J. Guiot

\section{References}

Abrantes, F., Lebreiro, S., Rodrigues, T., Gil, I., Bartels-Jónsdóttir, H., Oliveira, P., Kissel, C., and Grimalt, J. O.: Shallow-marine 
sediment cores record climate variability and earthquake activity off Lisbon (Portugal) for the last 2000 years, Quaternary Sci. Rev., 24, 2477-2494, doi:10.1016/j.quascirev.2004.04.009, 2005.

Anand, P., Elderfield, H., and Conte, M. H.: Calibration of $\mathrm{Mg} / \mathrm{Ca}$ thermometry in planktonic foraminifera from a sediment trap time series, Paleoceanography, 18, 1050, doi:10.1029/2002PA000846, 2003.

André, G., Garreau, P., Garnier, V., and Fraunié, P.: Modelled variability of the sea surface circulation in the North-western Mediterranean Sea and in the Gulf of Lions, Ocean Dynam., 55, 294-308, 2005.

Appleby, P. G. and Oldfield, F.: Application of Lead-210 to Sedimentation Studies, Clarendon Press, Oxford, Chapt. 21, 731778, 1992.

Ausín, B., Flores, J. A., Sierro, F. J., Cacho, I., HernándezAlmeida, I., Martrat, B., and Grimalt, J. O.: Atmospheric patterns driving Holocene productivity in the Alboran Sea (Western Mediterranean): a multiproxy approach, Holocene, 25, 1-13, doi:10.1177/0959683614565952, 2015.

Bárcena, M. A., Flores, J. A., Sierro, F. J., Pérez-Folgado, M., Fabres, J., Calafat, A., and Canals, M.: Planktonic response to main oceanographic changes in the Alboran Sea (Western Mediterranean) as documented in sediment traps and surface sediments, Mar. Micropaleontol., 53, 423-445, doi:10.1016/j.marmicro.2004.09.009, 2004.

Barker, S., Greaves, M., and Elderfield, H.: A study of cleaning procedures used for foraminiferal $\mathrm{Mg} / \mathrm{Ca}$ paleothermometry, Geochem. Geophy. Geosy., 4, 8407, doi:10.1029/2003GC000559, 2003.

Barker, S., Cacho, I., Benway, H., and Tachikawa, K.: Planktonic foraminiferal $\mathrm{Mg} / \mathrm{Ca}$ as a proxy for past oceanic temperatures: a methodological overview and data compilation for the Last Glacial Maximum, Quaternary Sci. Rev., 24, 821-834, doi:10.1016/j.quascirev.2004.07.016, 2005.

Barriendos, M. and Martin-Vide, J.: Secular climatic oscillations as indicated by catastrophic floods in the spanish mediterranean coastal area (14th-19th centuries), Climatic Change, 38, 473491, 1998.

Bé, A. W. H. and Hutson, W. H.: Ecology of planktonic foraminifera and biogeographic patterns of life and fossil assemblages in the Indian Ocean, Micropaleontology, 23, 369-414, 1977.

Bemis, B. E., Spero, H. J., Bijma, J., and Lea, D. W.: Reevaluation of the oxygen isotopic composition of planktonic foraminifera: Experimental results and revised paleotemperature equations, Paleoceanography, 13, 150-160, doi:10.1029/98PA00070, 1998.

Benito, G., Sopeña, A., Sánchez-Moya, Y., Machado, M. J., and Pérez-González, A.: Palaeoflood record of the Tagus River (Central Spain) during the Late Pleistocene and Holocene, Quaternary Sci. Rev., 22, 1737-1756, doi:10.1016/S0277-3791(03)00133-1, 2003.

Béthoux, J. P.: Mean water fluxes across sections in the Mediterranean Sea, evaluated in the basis of water and salt budgets and of observed salinities, Oceanol. Acta, 3, 79-88, 1980.

Bond, G., Kromer, B., Beer, J., Muscheler, R., Evans, M. N., Showers, W., Hoffmann, S., Lottibond, R., Hajdas, I., and Bonani, G.: Persistent solar influence on North Atlantic climate during the holocene, Science, 294, 2130-2136, doi:10.1126/science.1065680, 2001.
Bosc, E., Bricaud, A., and Antoine, D.: Seasonal and interannual variability in algal biomass and primary production in the Mediterranean Sea, as derived from 4 years of SeaWiFS observations, Global Biogeochem. Cy., 18, 2003-2034, doi:10.1029/2003GB002034, 2004.

Büntgen, U., Tegel, W., Nicolussi, K., McCormick, M., Frank, D., Trouet, V., Kaplan, J. O., Herzig, F., Heussner, K. U., Wanner, H., Luterbacher, J., and Esper, J.: 2500 years of European climate variability and human susceptibility, Science, 331, 578-82, doi:10.1126/science.1197175, 2011.

Cacho, I., Pelejero, C., Grimalt, J. O., Calafat, A., and Canals, M.: C37 alkenone measurements of sea surface temperature in the Gulf of Lions (NW Mediterranean), Org. Geochem., 30, 557566, 1999a.

Cacho, I., Grimalt, J. O., Pelejero, C., Canals, M., Sierro, F. J., Flores, J. A., and Shackleton, N.: Dansgaard-Oeschger and Heinrich event imprints in Alboran Sea paleotemperatures, Paleoceanography, 14, 698-705, 1999b.

Cacho, I., Grimalt, J. O., Sierro, F. J., Shackleton, N., and Canals, M.: Evidence for enhanced Mediterranean thermohaline circulation during rapid climatic coolings, Earth Planet. Sc. Lett., 183, 417-429, doi:10.1016/S0012-821X(00)00296-X, 2000.

Cacho, I., Grimalt, J., Canals, M., Sbaffi, L., Shackleton, N. J., Schönfeld, J., and Zahn, R.: Variability of the western Mediterranean Sea surface temperature during the last 25000 years ans its connection with the Northern Hemisphere climatic changes, Paleoceanography, 16, 40-52, 2001.

Cacho, I., Shackleton, N., Elderfield, H., Sierro, F. J., and Grimalt, J. O.: Glacial rapid variability in deep-water temperature and $\delta^{18} \mathrm{O}$ from the Western Mediterranean Sea, Quaternary Sci. Rev., 25, 3294-3311, doi:10.1016/j.quascirev.2006.10.004, 2006.

Canals, M., Puig, P., De Madron, X. D., Heussner, S., Palanques, A., and Fabres, J.: Flushing submarine canyons, Nature, 444, 354357, doi:10.1038/nature05271, 2006.

Chen, L., Zonneveld, K. A. F., and Versteegh, G. J. M.: The Holocene Paleoclimate of the Southern Adriatic Sea region during the "Medieval Climate Anomaly" reflected by organic walled dinoflagellate cysts, Holocene, 23, 645-655, doi:10.1177/0959683612467482, 2013.

Cléroux, C., Cortijo, E., Anand, P., Labeyrie, L., Bassinot, F., Caillon, N., and Duplessy, J. C.: $\mathrm{Mg} / \mathrm{Ca}$ and $\mathrm{Sr} / \mathrm{Ca}$ ratios in planktonic foraminifera: proxies for upper water column temperature reconstruction, Paleoceanography, 23, PA3214, doi:10.1029/2007PA001505, 2008.

Combourieu Nebout, N., Turon, J., Zahn, R., Capotondi, L., Londeix, L., and Pahnke, K.: Enhanced aridity and atmospheric high-pressure stability over the western Mediterranean during the North Atlantic cold events of the past 50 k.y., Geology, 30, 863866, 2002.

Combourieu Nebout, N., Peyron, O., Dormoy, I., Desprat, S., Beaudouin, C., Kotthoff, U., and Marret, F.: Rapid climatic variability in the west Mediterranean during the last 25000 years from high resolution pollen data, Clim. Past, 5, 503-521, doi:10.5194/cp5-503-2009, 2009.

Conte, M. H., Sicre, M. A., Rühlemann, C., Weber, J. C., Schulte, S., Schulz-Bull, D., and Blanz, T.: Global temperature calibration of the alkenone unsaturation index $\left(\mathrm{U}_{37}^{K^{\prime}}\right)$ in surface waters and comparison with surface sediments, Geochem. Geophy. Geosy., 7, Q02005, doi:10.1029/2005GC001054, 2006. 
Coplen, T.: New guidelines for reporting stable hydrogen, carbon, and oxygen isotope-ratio data, Geochim. Cosmochim. Ac., 60, 3359-3360, 1996.

Corella, J. P., Moreno, A., Morellón, M., Rull, V., Giralt, S., Rico, M. T., Pérez-Sanz, A., and Valero-Garcés, B. L.: Climate and human impact on a meromictic lake during the last 6000 years (Montcortés Lake, Central Pyrenees, Spain), J. Palaeolimnol., 46, 351-367, 2011.

Craig, H.: The measurement of oxygen isotope paleotemperatures, in: Stable Isotopes in Oceanographic Studies and Paleotemperatures, edited by: Tongiorgi, E., Consiglio Nazionale delle Ricerche, Laboratorio di Geologia Nucleare, Pisa, 1-24, 1965.

Dahl-Jensen, D., Mosegaard, K., Gundestrup, N., Clow, G. D., Johnses, S. J., Hansen, A. W., and Balling, N.: Past temperatures directly from the Greenland ice sheet, Science, 282, 268-271, 1998.

Demirov, E. and Pinardi, N.: Simulation of the Mediterranean Sea circulation from 1979 to 1993: Part I. The interannual variability, J. Marine Syst., 33-34, 23-50, 2002.

Di Bella, L., Frezza, V., Bergamin, L., Carboni, M. G., Falese, F., Mortorelli, E., Tarragoni, C., and Chiocci, F. L.: Foraminiferal record and high-resolution seismic stratigraphy of the Late Holocene succession of the submerged Ombrone River delta (Northern Tyrrhenian Sea, Italy), Quaternary Int., 328-329, 287300, 2014.

D'Ortenzio, F. and Ribera d'Alcalà, M.: On the trophic regimes of the Mediterranean Sea: a satellite analysis, Biogeosciences, 6, 139-148, doi:10.5194/bg-6-139-2009, 2009.

Eglinton, T. I., Conte, M. H., Eglinton, G., and Hayes, J. M.: Proceedings of a workshop on alkenone-based paleoceanographic indicators, Geochem. Geophy. Geosy., 2, 2000GC000122, doi:10.1029/2000GC000122, 2001.

Elderfield, H. and Ganssen, G.: Past temperature and $\delta^{18} \mathrm{O}$ of surface ocean waters inferred from foraminiferal $\mathrm{Mg} / \mathrm{Ca}$ ratios, Nature, 405, 442-445, 2000.

Esper, J., Frank, D. C., Büntgen, U., Verstege, A., Luterbacher, J., and Xoplaki, E.: Long-term drought severity variations in Morocco, Geophys. Res. Lett., 34, L17702, doi:10.1029/2007GL030844, 2007.

Esper, J., Düthorn, E., Krusic, P. J., Timonen, M., and Büntgen, U.: Northern European summer temperature variations over the Common Era from integrated tree-ring density records, J. Quaternary Sci., 29, 487-494, doi:10.1002/jqs.2726, 2014.

Estrada, M., Vives, F., and Alcaraz, M.: Life and productivity in the open sea, in: Western Mediterranean, edited by: Margalef, R., Oxford, Pergamon Press, 148-197, 1985.

Fanget, A. S., Bassetti, M. A., Arnaud, M., Chioleau, J. F., Cossa, D., Goineau, A.,Fontanier, C., Buscail, R., Jouet, G., Maillet, G. M., Negri, A., Dennielou, B., and Berné, S.: Historical evolution and extreme climate events during the last 400 years on the Rhone prodelta (NW Mediterranean), Mar. Geol., 346, 375-391, doi:10.1016/j.margeo.2012.02.007, 2013.

Ferguson, J. E., Henderson, G. M., Kucera, M., and Rickaby, R. E. M.: Systematic change of foraminiferal $\mathrm{Mg} / \mathrm{Ca}$ ratios across a strong salinity gradient, Earth Planet. Sc. Lett., 265, 153-166, doi:10.1016/j.epsl.2007.10.011, 2008.

Fleitmann, D., Cheng, H., Badertscher, S., Edwards, R. L., Mudelsee, M., Gktürk, O. M., Fankhauser, A., Pickering, R., Raible, C. C., Matter, A., Kramers, J., and Tüysüz, O.: Timing and climatic impact of Greenland interstadials recorded in stalagmites from northern Turkey, Geophys. Res. Lett., 36, L19707, doi:10.1029/2009GL040050, 2009.

Fletcher, W. J. and Sánchez Goñi, M. F.: Orbital and sub-orbitalscale climate impacts on vegetation of the western Mediterranean basin over the last $48000 \mathrm{yr}$, Quaternary Res., 70, 451-464, 2008.

Fletcher, W. J., Debret, M., and Sanchez Goñi, M.: Mid-Holocene emergence of a low-frequency millennial oscillation in western Mediterranean climate: implications for past dynamics of the North Atlantic atmospheric westerlies, Holocene, 23, 153-166, doi:10.1177/0959683612460783, 2012.

Frigola, J.: Variabilitat climàtica ràpida a la conca occidental del Mediterrani: registre sedimentològic, $\mathrm{PhD}$ Thesis, Dept. of Stratigraphy, Paleontology and Marine Geosciences, University of Barcelona, Spain, 2012.

Frigola, J., Moreno, A., Cacho, I., Canals, M., Sierro, F. J., Flores, J. A., Grimalt, J. O., Hodell, D. A., and Curtis, J. H.: Holocene climate variability in the western Mediterranean region from a deepwater sediment record, Paleoceanography, 22, PA2209, doi:10.1029/2006PA001307, 2007.

Frigola, J., Moreno, A., Cacho, I., Canals, M., Sierro, F. J., Flores, J. A., and Grimalt, J. O.: Evidence of abrupt changes in Western Mediterranean Deep Water circulation during the last $50 \mathrm{kyr}$ : a high-resolution marine record from the Balearic Sea, Quaternary Int., 181, 88-104, doi:10.1016/j.quaint.2007.06.016, 2008.

Frisia, S., Borsato, A., Preto, N., and McDermott, F.: Late Holocene annual growth in three Alpine stalagmites records the influence of solar activity and the North Atlantic Oscillation on winter climate, Earth Planet. Sc. Lett., 216, 411-424, 2003.

Ganssen, G. M. and Kroon, D.: The isotopic signature of planktonic foraminifera from NE Atlantic surface sediments: implications for the reconstruction of past oceanic conditions, J. Geol. Soc. London, 157, 693-699, 2000.

Gao, C., Robock, A., and Ammann, C.: Volcanic forcing of climate over the past 1500 years: An improved ice core-based index for climate models, J. Geophys. Res., 113, D23111, doi:10.1029/2008JD010239, 2008.

Giorgi, F.: Climate change hot-spots, Geophys. Res. Lett., 33, L08707, doi:10.1029/2006GL025734, 2006.

González-Álvarez, R., Bernárdez, P., Pena, L. D., Francés, G., Prego, R., Diz, P., and Vilas, F.: Paleoclimatic evolution of the Galician continental shelf (NW of Spain) during the last 3000 years: from a storm regime to present conditions, J. Mar. Syst., 54, 245-260, 2005.

Goudeau, M. L. S., Reichart, G. J., Wit, J. C., de Nooijer, L. J., Grauel, A. L., Bernasconi, S. M., and de Lange, G. J.: Seasonality variations in the Central Mediterranean during climate change events in the Late Holocene, Palaeogeogr. Palaeocl., 418, 304 318, 2015.

Goy, J. L, Zazo, C., and Dabrio, C. J.: A beach-ridge progradation complex reflecting periodical sea-level and climate variability during the Holocene (Gulf of Almeria, Western Mediterranean), Geomorphology, 50, 251-268, 2003.

Gray, S. T., Graumlich, L. J., Betancourt, J. L., and Pederson, G. T.: A tree-ring based reconstruction of the Atlantic Multidecadal Oscillation since 1567 A. D., Geophys. Res. Lett., 31, L12205, doi:10.1029/2004GL019932, 2004. 
Griggs, C., DeGaetano, A., Kuniholm, P., and Newton, M.: A regional high-frequency reconstruction of May-June precipitation in the north Aegean from oak tree rings, AD 1089-1989, Int. J. Climatol., 27, 1075-1089, 2007.

Grauel, A. L., Goudeau, M. L. S., de Lange, G. J., and Bernasconi, S. M.: Climate of the past 2500 years in the Gulf of Taranto, central Mediterranean Sea: a high-resolution climate reconstruction based on $\delta^{18} \mathrm{O}$ and $\delta^{13} \mathrm{C}$ of Globigerinoides ruber (white), Holocene, 23, 1440-1446, doi:10.1177/0959683613493937, 2013.

Guemas, V., García-Serrano, J., Mariotti, A., Doblas-Reyes, F., and Caron, L. P.: Prospects for decadal climate prediction in the Mediterranean region, Q. J. Roy. Meteor. Soc., 141, 580-597, doi:10.1002/qj.2379, 2014.

Hernández-Almeida, I., Bárcena, M. Á., Flores, J. A., Sierro, F. J., Sánchez-Vidal, A., and Calafat, A.: Microplankton response to environmental conditions in the Alboran Sea (Western Mediterranean): one year sediment trap record, Mar. Micropaleontol., 78, 14-24, doi:10.1016/j.marmicro.2010.09.005, 2011.

Holzhauser, H., Magny, M., and Heinz, J.: Glacier and lakelevel variations in west-central Europe over the last 3500 years, Holocene, 15, 789-801, 2005.

Hönisch, B., Allen, K. A., Lea, D. W., Spero, H. J., Eggins, S. M., Arbuszewski, J., DeMenocal, P., Rosenthal, Y., Russell, A. D., and Elderfield, H.: The influence of salinity on $\mathrm{Mg} / \mathrm{Ca}$ in planktic foraminifers - evidence from cultures, core-top sediments and complementary $\delta^{18} \mathrm{O}$, Geochim. Cosmochim. Ac., 121, 196213, 2013.

Hoogakker, B. A. A., Klinkhammer, G. P., Elderfield, H., Rohling, E. J., and Hayward, C.: $\mathrm{Mg} / \mathrm{Ca}$ paleothermometry in high salinity environments, Earth Planet. Sc. Lett., 284, 583-589, doi:10.1016/j.eps1.2009.05.027, 2009.

Huang, S.: Merging information from different resources for new insights into climate change in the past and future, Geophys. Res. Lett., 31, 1-4, doi:10.1029/2004GL019781, 2004.

Hughes, M. K. and Diaz, H. F.: Was there a "Medieval warm period", and if so, where and when?, Climatic Change, 26, 109$142,1994$.

Hurrell, J. W.: Decadal Trends in the North Atlantic Oscillation: regional temperatures and precipitation, Science, 269, 676-679, doi:10.1126/science.269.5224.676, 1995.

Incarbona, A., Ziveri, P., Di Stefano, E., Lirer, F., Mortyn, G., Patti, B., Pelosi, N., Sprovieri, M., Tranchida, G., Vallefuoco, M., Albertazzi, S., Bellucci, L. G., Bonanno, A., Bonomo, S., Censi, P., Ferraro, L., Giuliani, S., Mazzola, S., and Sprovieri, R.: The Impact of the Little Ice Age on Coccolithophores in the Central Mediterranea Sea, Clim. Past, 6, 795-805, doi:10.5194/cp-6795-2010, 2010.

Jalut, G., Esteban Amat, A., Mora, S. R., Fontugne, M., Mook, R., Bonnet, L., and Gauquelin, T.: Holocene climatic changes in the western Mediterranean: installation of the Mediterranean climate, CR. Acad. Sci. II, 325, 327-334, 1997.

Jalut, G., Esteban Amat, A., Bonnet, L., Gauquelin, T., and Fontugne, M.: Holocene climatic changes in the Western Mediterranean, from south-east France to south-east Spain, Palaeogeogr. Palaeocl., 160, 255-290, 2000.

Joerin, U. E., Stocker, T. F., Schlu, C., and Physics, E.: Multicentury glacier fluctuations in the Swiss Alps during the Holocene, Holocene, 16, 697-704, 2006.
Kaufman, D. S., Schneider, D. P., McKay, N. P., Ammann, C. M., Bradley, R. S., Bria, K. R., Miller, G. H., Otto-Bliesner, B. L., Overpeck, J. P., and Vinther, B. M.: Recent warming reverses long-term arctic cooling, Science, 325, 1236-1239, doi:10.1126/science.1173983, 2009.

Kobashi, T., Kawamura, K., Severinghaus, J. P., Barnola, J. M., Nakaegawa, T., Vinther, B. M., Johnsen, S. J., and Box, J. E.: High variability of Greenland surface temperature over the past 4000 years estimated from trapped air in an ice core, Geophys. Res. Lett., 38, L21501, doi:10.1029/2011GL049444, 2011.

Krishnaswami, S., Lal, D., Martin, J. M., and Meybeck, M.: Geochronology of lake sediments, Earth. Planet. Sc. Lett, 11, 407-414, 1971.

Labuhn, I., Genty, D., Vonhof, H., Bourdin, C., Blamart, D., Douville, E., Ruan, J., Cheng, H., Edwards, R. L., Pons-Branchu, E., and Pierre, M.: A high-resolution fluid inclusion $\delta^{18} \mathrm{O}$ record from a stalagmite in SW France: modern calibration and comparison with multiple proxies, Quaternary Sci. Rev., 110, 152-165, doi:10.1016/j.quascirev.2014.12.021, 2015.

Lacombe, H., Gascard, J. C, Cornella, J., and Béthoux, J. P.: Response of the Mediterranean to the water and energy fluxes across its surface, on seasonal and interannual scales, Oceanol. Acta, 4, 247-255, 1981.

Lacombe, H., Tchernia, P., and Gamberoni, L.: Variable bottom water in the Western Mediterranean basin, Prog. Oceanogr., 14, 319-338, 1985.

Larsen, L. B., Vinther, B. M., Bria, K. R., Melvin, T. M., Clausen, H. B., Jones, P. D., Siggaard-Andersen, M. L., Hammer, C. U., Eronen, M., Grudd, H., Gunnarson, B. E., Hantemirov, R. M., Naurzbaev, M. M., and Nicolussi, K.: New ice core evidence for a volcanic cause of the A.D. 536 dust veil, Geophys. Res. Lett., 35, 1-5, doi:10.1029/2007GL032450, 2008.

Laskar, J., Robutel, P., Joutel, F., Gastineau, M., Correia, A. C. M., and Levrard, B.: A longterm numerical solution for the insolation quantities of the Earth, Astron. Astrophys., 285, 261-285, 2004.

Lea, D. W., Mashiotta, T. A., and Spero, H. J.: Controls on magnesium and strontium uptake in planktonic foraminifera determined by live culturing, Geochim. Cosmochim. Ac., 63, 2369-2379, 1999.

Lea, D. W., Pak, D. K., and Paradis, G.: Influence of volcanic shards on foraminiferal $\mathrm{Mg} / \mathrm{Ca}$ in a core from the Galápagos region, Geochem. Geophy. Geosy., 6, Q11P04, doi:10.1029/2005GC000970, 2005.

Lebreiro, S. M., Francés, G., Abrantes, F. F. G., Diz, P., BartelsJónsdóttir, H. B., Stroynowski, Z. N., Gil, I. M., Pena, L. D., Rodrigues, T., Jones, P. D., Nombela, M. A., Alejo, I., Bria, K. R., Harris, I., and Grimalt, J. O.: Climate change and coastal hydrographic response along the Atlantic Iberian margin (Tagus Prodelta and Muros Ría) during the last two millennia, Holocene, 16, 1003-1015, 2006.

Lehner, F., Raible, C. C., and Stocker, T. F.: Testing the robustness of a precipitation proxy-based North Atlantic Oscillation reconstruction, Quaternary Sci. Rev., 45, 85-94, doi:10.1016/j.quascirev.2012.04.025, 2012.

Lionello, P.: The Climate of the Mediterranean Region: From the Past to the Future, Elsevier Science, Burlington, MA, 2012.

Lionello, P. and Sanna, A.: Mediterranean wave climate variability and its links with NAO and Indian Monsoon, Clim. Dynam., 25, 611-623, doi:10.1007/s00382-005-0025-4, 2005. 
Lionello, P., Malanott-Rizzoli, R., Boscolo, R., Alpert, P., Artale, V., Li, L., Luterbacher, J., May, W., Trigo, R., Tsimplis, M., Ulbrich, U., and Xoplaki, E.: The Mediterranean climate: An overview of the main characteristics and issues, in: Mediterranean Climate Variability (MedClivar), Elsevier, Amsterdam, 1-26, 2006.

Lirer, F., Sprovieri, M., Ferraro, L., Vallefuoco, M., Capotondi, L., Cascella, A., Petrosino, P., Insinga, D. D., Pelosi, N., Tamburrino, S., and Lubritto, C.: Integrated stratigraphy for the Late Quaternary in the eastern Tyrrhenian Sea, Quaternary Int., 292, 71-85, doi:10.1016/j.quaint.2012.08.2055, 2013.

Lirer, F., Sprovieri, M., Vallefuoco, M., Ferraro, L., Pelosi, N., Giordano, L., and Capotondi, L.: Planktonic foraminifera as bioindicators for monitoring the climatic changes that have occurred over the past 2000 years in the southeastern Tyrrhenian Sea, Integr. Zool., 9, 542-54, doi:10.1111/1749-4877.12083, 2014.

Luterbacher, J., Dietrich, D., Xoplaki, E., Grosjean, M., and Wanner, H.: European seasonal and annual temperature variability, trends, and extremes since 1500, Science, 303, 1499-1503, doi:10.1126/science.1093877, 2004.

Malanotte-Rizzoli, P., Artale, V., Borzelli-Eusebi, G. L., Brenner, S., Crise, A., Gacic, M., Kress, N., Marullo, S., Ribera d'Alcalà, M., Sofianos, S., Tanhua, T., Theocharis, A., Alvarez, M., Ashkenazy, Y., Bergamasco, A., Cardin, V., Carniel, S., Civitarese, G., D’Ortenzio, F., Font, J., Garcia-Ladona, E., Garcia-Lafuente, J. M., Gogou, A., Gregoire, M., Hainbucher, D., Kontoyannis, H., Kovacevic, V., Kraskapoulou, E., Kroskos, G., Incarbona, A., Mazzocchi, M. G., Orlic, M., Ozsoy, E., Pascual, A., Poulain, P.-M., Roether, W., Rubino, A., Schroeder, K., Siokou-Frangou, J., Souvermezoglou, E., Sprovieri, M., Tintoré, J., and Triantafyllou, G.: Physical forcing and physical/biochemical variability of the Mediterranean Sea: a review of unresolved issues and directions for future research, Ocean Sci., 10, 281-322, doi:10.5194/os-10-281-2014, 2014.

Mangini, A., Spötl, C., and Verdes, P.: Reconstruction of temperature in the Central Alps during the past $2000 \mathrm{yr}$ from a $\delta^{18} \mathrm{O}$ stalagmite record, Earth. Planet. Sc. Lett., 235, 741-751, 2005.

Mann, M. E., Zhang, Z., Hughes, M. K., Bradley, R. S., Miller, S. K., Rutherford, S., and Ni, F.: Proxy-based reconstructions of hemispheric and global surface temperature variations over the past two millennia, P. Natl. Acad. Sci. USA, 105, 13252-13257, 2008.

Mann, M. E., Zhang, Z., Rutherford, S., Bradley, R. S., Hughes, M. K., Shindell, D., Ammann, C., Faluvegi, G., and Ni, F.: Global signatures and dynamical origins of the little ice age and medieval climate anomaly, Science, 326, 1256-1260, 2009.

Marchal, O., Cacho, I., Stocker, T. F., Grimalt, J. O., Calvo, E., Martrat, B., Shackleton, N., Vautravers, M., Cortijo, E., Van Kreveld, S., Andersson, C., Ko, N., Chapman, M., Sbaffi, L., Duplessy, J., Sarnthein, M., and Turon, J.: Apparent long-term cooling of the sea surface in the northeast Atlantic and Mediterranean during the Holocene, Quaternary Sci. Rev., 21, 455-483, 2002.

Mariotti, A.: Decadal climate variability and change in the Mediterranean Region, Sci. Technol. Infus. Clim. Bull., Climate Test Bed Joint Seminar Series, Maryland, US National Oceanic and Atmospheric Administration, 1-5, 2011.

Martín-Chivelet, J., Muñoz-García, M. B., Edwards, R. L., Turrero, M. J., and Ortega, A. I.: Land surface temperature changes in Northern Iberia since $4000 \mathrm{yr}$ BP, based on $\delta^{13} \mathrm{C}$ of speleothems, Global Planet. Change, 77, 1-12, doi:10.1016/j.gloplacha.2011.02.002, 2011.

Martín-Puertas, C., Valero-Garcés, B. L., Brauer, A., Mata, M. P., Delgado-Huertas, A., and Dulski, P.: The Iberian-Roman Humid Period (2600-1600 cal yr BP) in the Zoñar Lake varve record (Andalucía, Southern Spain), Quaternary Res., 71, 108120, doi:10.1016/j.yqres.2008.10.004, 2008.

Martínez-Cortizas, A., Pontevedra-Pombal, X., García-Rodeja, E., Nóvoa-Muñoz, J. C., and Shotyk, W.: Mercury in a Spanish Peat Bog: archive of climate change and atmospheric metal deposition, Science, 284, 939-942, 1999.

Martrat, B., Grimalt, J. O., Lopez-Martinez, C., Cacho, I., Sierro, F. J., Flores, J. A., Zahn, R., Canals, M., Curtis, J. H., and Hodell, D. A.: Abrupt temperature changes in the Western Mediterranean over the past 250000 years, Science, 306, 1762-1765, doi:10.1126/science.1101706, 2004.

Marullo, S., Artale, V., and Santoleri, R.: The SST multi-decadal variability in the Atlantic-Mediterranean region and its relation to AMO, J. Climate, 24, 4385-4401, doi:10.1175/2011JCLI3884.1, 2011.

Mashiotta, T. A., Lea, D. W., and Spero, H. J.: Glacial-interglacial changes in Subantarctic sea surface temperature and $\delta^{18} \mathrm{O}$-water using foraminiferal $\mathrm{Mg}$, Earth Planet. Sc. Lett., 170, 417-432, 1999.

Masqué, P., Fabres, J., Canals, M., Sanchez-Cabeza, J. A., SanchezVidal, A., Cacho, I., Calafat, A. M., and Bruach, J. M.: Accumulation rates of major constituents of hemipelagic sediments in the deep Alboran Sea: a centennial perspective of sedimentary dynamics, Mar. Geol., 193, 207-233, 2003.

Matthews, J. A. and Bria, K. R.: The "Little ice age": re-evaluation of an evolving concept, Geogr. Ann. A, 87, 17-36, 2005.

Mauffret, A.: Etude géodynamique de la marge des Illes Baléares, Mémoires de la Société Géologique de France LVI, 1-96, 1979.

Mayewski, P. A., Rohling, E. E., Stager, J. C., Karlen, W., Maasch, K. A., Meeker, L. D., Meyerson, E. A., Gasse, F., van Kreveld, S., Holmgren, K., Lee-Thorp, J., Rosqvist, G. Rack, F., Staubwasser, M., Schneider, R. R., and Steig, E. J.: Holocene climate variability, Quaternary Res., 62, 243-255, 2004.

McConnell, M. C. and Thunell, R. C.: Calibration of the planktonic foraminiferal $\mathrm{Mg} / \mathrm{Ca}$ paleothermometer: sediment trap results from the Guaymas Basin, Gulf of California, Paleoceanography, 20, PA2016, doi:10.1029/2004PA001077, 2005.

McGregor, H. V., Evans, M. N., Goosse, H., Leduc, G., Martrat, B., Addison, J. A., Graham Mortyn, P., Oppo, D. W., Seidenkrantz, M.-S., Sicre, M.-A., Phipps, S. J., Selvaraj, K., Thirumalai, K., Filipsson, H. L., and Ersek, V.: Robust global ocean cooling trend for the pre-industrial Common Era, Nat. Geosci., 8, 671-677, doi:10.1038/ngeo2510, 2015.

MEDAR GROUP, MEDATLAS/2002 European Project: Mediterranean and Black Sea Database of Temperature Salinity and BioChemical Parameters, Climatological Atlas, Institut Français de Recherche pour L'Exploitation de la Mer (IFREMER), Edition/Instituto Nazionale di Oceanografia e di Geofisica Sperimentale (OGS), 2002.

Medoc, G.: Observation of formation of Deep Water in the Mediterranean Sea, Nature, 227, 1037-1040, 1970.

Millán, M. M., Estrela, M. J., Sanz, M. J., Mantilla, E., Martín, M., Pastor, F., Salvador, R., Vallejo, R., Alonso, L., Gangoiti, G., Ilardia, J. L., Navazo, M., Albizuri, A., Artiñano, B., Ciccioli, P., 
Kallos, G., Carvalho, R. A., Andrés, D., Ho, A., Werhahn, J., Seufert, G., and Versino, B.: Climatic feedbacks and desertification: the Mediterranean Model, J. Climate, 18, 684-701, 2005.

Millot, C.: Circulation in the Western Mediterranean Sea, J. Mar. Syst., 20, 423-442, 1999.

Morellón, M., Pérez-Sanz, A., Corella, J. P., Büntgen, U., Catalán, J., González-Sampériz, P., González-Trueba, J. J., López-Sáez, J. A., Moreno, A., Pla-Rabes, S., Saz-Sánchez, M. Á., Scussolini, P., Serrano, E., Steinhilber, F., Stefanova, V., VegasVilarrúbia, T., and Valero-Garcés, B.: A multi-proxy perspective on millennium-long climate variability in the Southern Pyrenees, Clim. Past, 8, 683-700, doi:10.5194/cp-8-683-2012, 2012.

Moreno, A., Cacho, I., Canals, M., Prins, M. A., SánchezGoñi, M. F., Grimalt, J. O., and Weltje, G. J.: Saharan Dust Transport and High-Latitude Glacial Climatic Variability: the Alboran Sea Record, Quaternary Res., 58, 318-328, doi:10.1006/qres.2002.2383, 2002.

Moreno, A., Cacho, I., Canals, M., Grimalt, J. O., Sánchez-Goñi, M. F., Shackleton, N., and Sierro, F. J.: Links between marine and atmospheric processes oscillating on a millennial time-scale. A multi-proxy study of the last $50000 \mathrm{yr}$ from the Alboran Sea (Western Mediterranean Sea), Quaternary Sci. Rev., 24, 16231636, doi:10.1016/j.quascirev.2004.06.018, 2005.

Moreno, A., Valero-Garcés, B. L., González-Sampériz, P., and Rico, M.: Flood response to rainfall variability during the last 2000 years inferred from the Taravilla Lake record (Central Iberian Range, Spain), J. Paleolimnol., 40, 943-961, doi:10.1007/s10933-008-9209-3, 2008.

Moreno, A., Pérez, A., Frigola, J., Nieto-Moreno, V., RodrigoGámiz, M., Martrat, B., González-Sampériz, P., Morellón, M., Martín-Puertas, C., Pablo, J., Belmonte, Á., Sancho, C., Cacho, I., Herrera, G., Canals, M., Grimalt, J. O., Jiménez-Espejo, F., Martínez-Ruiz, F., Vegas-Vilarrúbia, T., and Valero-Garcés, B. L.: The Medieval Climate Anomaly in the Iberian Peninsula reconstructed from marine and lake records, Quaternary Sci. Rev., 43, 16-32, doi:10.1016/j.quascirev.2012.04.007, 2012.

Morhange, C., Marriner, N., Excoffon, P., Bonnet, S., Flaux, C., Zibrowius, H., Goiran, J. P., and El Amouri, M.: Relative Sea-Level Changes During Roman Times in the Northwest Mediterranean: the 1st Century AD. Fish Tank of Forum Julii, Fréjus, France, Geoarchaeology, 28, 363-372, doi:10.1002/gea.21444, 2013.

Mulitza, S., Boltovskoy, D., Donner, B., Meggers, H., Paul, A., and Wefer, G.: Temperature : $\delta^{18} \mathrm{O}$ relationships of planktonic foraminifera collected from surface waters, Palaeogeogr. Palaeoecol., 202, 143-152, doi:10.1016/S0031-0182(03)006333, 2003.

Nieto-Moreno, V., Martínez-Ruiz, F., Giralt, S., Jiménez-Espejo, F., Gallego-Torres, D., Rodrigo-Gámiz, M., García-Orellana, J., Ortega-Huertas, M., and de Lange, G. J.: Tracking climate variability in the western Mediterranean during the Late Holocene: a multiproxy approach, Clim. Past, 7, 1395-1414, doi:10.5194/cp7-1395-2011, 2011.

Nieto-Moreno, V., Martínez-Ruiz, F., Willmott, V., García-Orellana, J., and Masqué, P.: Organic geochemistry climate conditions in the westernmost Mediterranean over the last two millennia: an integrated biomarker approach, Org. Geochem., 55, 1-10, doi:10.1016/j.orggeochem.2012.11.001, 2013.
Olsen, J., Anderson, N. J., and Knudsen, M. F.: Variability of the North Atlantic Oscillation over the past 5200 years, Nat. Geosci., 5, 808-812, doi:10.1038/ngeo1589, 2012.

Ortega, P., Lehner, F., Swingedouw, D., Masson-Delmotte, V., Raible, C. C., Casado, M., and Yiou, P.: A model-tested North Atlantic Oscillation reconstruction for the past millennium, Nature, 523, 71-74, doi:10.1038/nature14518, 2015.

PAGES: Science Plan and Implementation Strategy, IGBP Report No. 57, IGBP Secretariat, Stockholm, 2009.

PAGES 2K Consortium: Continental-scale temperature variability during the past two millennia, Nature, 6, 339-346, doi:10.1038/NGEO1797, 2013.

Pastor, F.: Ciclogénesis intensas en la cuenca occidental del Mediterráneo y temperatura superficial del mar: modelización y evaluación de las áreas de recarga, PhD Thesis, Dept. of Astronomy and Meteorology, University of Barcelona, Spain, 2012.

Pastor, F., Estrela, M., Peñarrocha, D., and Millán, M.: Torrential rains on the Spanish Mediterranean Coast: modeling the effects of the sea surface temperature, J. Appl. Meteorol., 40, 1180 1195, 2001.

Patton, G. M., Martin, P. A., Voelker, A., and Salgueiro, E.: Multiproxy comparison of oceanographic temperature during Heinrich Events in the eastern subtropical Atlantic, Earth Planet. Sc. Lett., 310, 45-58, doi:10.1016/j.epsl.2011.07.028, 2011.

Pena, L. D., Calvo, E., Cacho, I., Eggins, S., and Pelejero, C.: Identification and removal of Mn-Mg-rich contaminant phases on foraminiferal tests: implications for $\mathrm{Mg} / \mathrm{Ca}$ past temperature reconstructions, Geochem. Geophy. Geosy., 6, Q09P02, doi:10.1029/2005GC000930, 2005.

Pena, L. D., Cacho, I., Calvo, E., Pelejero, C., Eggins, S., and Sadekov, A.: Characterization of contaminant phases in foraminifera carbonates by electron microprobe mapping, Geochem. Geophy. Geosy., 9, Q07012, doi:10.1029/2008GC002018, 2008.

Pena, L. D., Francés, G., Diz, P., Esparza, M., Grimalt, J. O., Nombela, M. A., and Alejo, I.: Climate fluctuations during the Holocene in NW Iberia: High and low latitude linkages, Cont. Shelf. Res., 30, 1487-1496, doi:10.1016/j.csr.2010.05.009, 2010.

Pierre, C.: The oxygen and carbon isotope distribution in the Mediterranean water masses, Mar. Geol., 153, 41-55, 1999.

Pinardi, N. and Masetti, E.: Variability of the large general circulation of the Mediterranean Sea from observations and modelling: a review, Palaeogeogr. Palaeocl., 158, 153-173, 2000.

Pinot, J. M., López-Jurado, J., and Riera, M.: The CANALES experiment (1996-1998), Interannual, seasonal, and mesoscale variability of the circulation in the Balearic Channels, Prog. Oceanogr., 55, 335-370, 2002.

Piva, A., Asioli, A., Trincardi, F., Schneider, R. R., and Vigliotti, L.: Late-Holocene climate variability in the Adriatic Sea (Central Mediterranean), Holocene, 18, 153-167, 2008.

Pla, S. and Catalan, J.: Chrysophyte cysts from lake sediments reveal the submillennial winter/spring climate variability in the northwestern Mediterranean region throughout the Holocene, Clim. Dynam., 24, 263-278, 2005.

Pujol, C. and Vergnaud-Grazzini, C.: Distribution patterns of live planktic foraminifers as related to regional hydrography and productive systems of the Mediterranean Sea, Mar. Micropaleontol., 25, 187-217, 1995. 
Reguera, M. I.: Respuesta del Mediterráneo Occidental a los cambios climáticos bruscos ocurridos durante el último glacial: estudio de las asociaciones de foraminíferos, PhD Thesis, Dept. of Geology, University of Salamanca, Spain, 2004.

Reimer, P. J., Bard, E., Bayliss, A., Beck, J. W., Blackwell, P. G., Bronk Ramsey, C., Buck, C. E., Edwards, R. L., Friedrich, M., Grootes, P. M., Guilderson, T. P., Haflidason, H., Hajdas, I., Hatté, C., Heaton, T. J., Hömann, D. L., Hogg, A. G., Hughen, K. A., Kaiser, K. F., Kromer, B., Manning, S. W., Niu, M., Reimer, R. W., Richards, D. A., Scott, M. E., Southon, J. R., Turney, C. S. M., and van der Plicht, J.: Intcal13 and Marine13 radiocarbon age calibration curves 0-50000 years cal BP, Radiocarbon, 55, 1869-1887, 2013.

Richter, T. O. and van der Gaast, S.: The Avaatech Core Scanner: technical description and applications to NE Atlantic sediments, in: New Ways of Looking at Sediment Core and Core Data, edited by: Rothwell, R. G., Geological Society Special Publication, London, 39-50, 2006.

Rigual-Hernández, A. S., Sierro, F. J., Bárcena, M. A., Flores, J. A., and Heussner, S.: Seasonal and interannual changes of planktic foraminiferal fluxes in the Gulf of Lions (NW Mediterranean) and their implications for paleoceanographic studies: two 12year sediment trap records, Deep-Sea Res. Pt. I, 66, 26-40, doi:10.1016/j.dsr.2012.03.011, 2012.

Rigual-Hernández, A. S., Bárcena, M. A., Jordan, R. W., Sierro, F. J., Flores, J. A., Meier, K. J., Beaufort, L., and Heussner, S.: Diatom fluxes in the NW Mediterranean: evidence from a 12year sediment trap record and surficial sediments, J. Plankton. Res., 35, 1-17, doi:10.1093/plankt/fbt055, 2013.

Roberts, N., Moreno, A., Valero-Garcés, B. L., Corella, J. P., Jones, M., Allcock, S., Woodbridge, J., Morellón, M., Luterbacher, J., Xoplaki, E., and Türkeş, M.: Palaeolimnological evidence for an east-west climate see-saw in the Mediterranean since $\mathrm{AD}$ 900, Global Planet. Change, 84-85, 23-34, doi:10.1016/j.gloplacha.2011.11.002, 2012.

Rodrigo-Gámiz, M., Martínez-Ruiz, S., Rampen, S., Schouten, S., and Sinninghe Damsté, J.: Sea surface temperature variations in the western Mediterranean Sea over the last $20 \mathrm{kyr}$ : a dualorganic proxy ( $\mathrm{U}_{37}^{k^{\prime}}$ and LDI) approach, Paleoceanography, 29, 87-98, doi:10.1002/2013PA002466, 2014.

Rogerson, M., Rohling, E. J., Weaver, P. P. E., and Murray, J. W.: The Azores Front since the Last Glacial Maximum, Earth Planet. Sc. Lett., 222, 779-789, doi:10.1016/j.epsl.2004.03.039, 2004.

Rohling, E., Hayes, A., De Rijk, S., Kroon, D., Zachariasse, W. J., and Eisma, D.: Abrupt cold spells in the northwest Mediterranean, Paleoceanography, 13, 316-322, 1998.

Sabatier, P., Dezileau, L., Colin, C., Briqueu, L., Bouchette, F., Martinez, P., Siani, G., Raynal, O., and Von Grafenstein, U.: 7000 years of paleostorm activity in the NW Mediterranean Sea in response to Holocene climate events, Quaternary Res., 77, 1-11, doi:10.1016/j.yqres.2011.09.002, 2012.

Sáez de Cámara, E., Gangoiti, G., Alonso, L., and Iza, J.: Daily precipitation in Northern Iberia: understanding the recent changes after the circulation variability in the North Atlantic sector, J. Geophys. Res., 120, 9981-10, doi:10.1002/2015JD023306, 2015.

Sanchez-Cabeza, J., Masqué, P., and Ani-Ragolta, I.: ${ }^{210} \mathrm{~Pb}$ and ${ }^{210} \mathrm{Po}$ analysis in sediments and soils by microwave acid digestion, J. Radioanal. Nucl. Ch., 227, 19-22, 1998.
Schiebel, R., Schmuker, B., Alves, M., and Hemleben, C.: Tracking the Recent and Late Pleistocene Azores front by the distribution of planktic foraminifers, J. Mar. Syst., 37, 213-227, 2002.

Schilman, B., Bar-Matthews, M., Almogilabin, A., and Luz, B.: Global climate instability reflected by Eastern Mediterranean marine records during the late Holocene, Palaeogeogr. Palaeocl., 176, 157-176, 2001.

Shackleton, N.: Attainment of isotopic equilibrium between ocean water and the benthonic foraminifera genus Uvigerina: isotopic changes in the ocean during the last glacial, CNRS, Colloq. Int., 219, 203-209, 1974.

Sicre, A., Ternois, Y., Miquel, J. C., and Marty, J. C.: Alkenones in the Northwestern Mediterranean sea: interannual variability and vertical transfer, Geophys. Res. Lett., 26, 1735-1738, 1999.

Sicre, M. A., Yiou, P., Eiríksson, J., Ezat, U., Guimbaut, E., Dahhaoui, I., Knudsen, K. L., Jansen, E., and Turon, J. L.: A 4500year reconstruction of sea surface temperature variability at decadal time-scales off North Iceland, Quaternary Sci. Rev., 27, 2041-2047, doi:10.1016/j.quascirev.2008.08.009, 2008.

Sierro, F. J., Hodell, D. A., Curtis, J. H., Flores, J. A., Reguera, I., Colmenero-Hidalgo, E., Bárcena, M. A., Grimalt, J. O., Cacho, I., Frigola, J., and Canals, M.: Impact of iceberg melting on Mediterranean thermohaline circulation during Heinrich events, Paleoceanography, 20, 1-13, doi:10.1029/2004PA001051, 2005.

Siokou-Frangou, I., Christaki, U., Mazzocchi, M. G., Montresor, M., Ribera d'Alcalá, M., Vaqué, D., and Zingone, A.: Plankton in the open Mediterranean Sea: a review, Biogeosciences, 7, 15431586, doi:10.5194/bg-7-1543-2010, 2010.

Steinhilber, F., Beer, J., and Fröhlich, C.: Total solar irradiance during the Holocene, Geophys. Res. Lett., 36, L19704, doi:10.1029/2009GL040142, 2009.

Steinhilber, F., Abreu, J. A., Beer, J., Brunner, I., Christl, M., Fischer, H., Heikkilä, U., Kubik, P. W., Mann, M., McCracken, K. G., Miller, H., Miyahara, H., Oerter, H., and Wilhelms, F.: 9400 years of cosmic radiation and solar activity from ice cores and tree rings, P. Natl. Acad. Sci. USA, 109, 5967-5971, doi:10.1073/pnas.1118965109, 2012.

Stine, S.: Extreme and persistent drought in California and Patagonia during medieval time, Nature, 369, 546-549, 1994.

Stothers, R. B.: Mystery cloud of AD 536, Nature, 307, 344-345, doi:10.1038/307344a0, 1984.

Stuiver, M. and Reimer, P. J.: Extended ${ }^{14} \mathrm{C}$ data base and revised Calib $3.0{ }^{14} \mathrm{C}$ age calibration program, Radiocarbon, 35, 215230, 1993.

Taricco, C., Ghil, M., Alessio, S., and Vivaldo, G.: Two millennia of climate variability in the Central Mediterranean, Clim. Past, 5, 171-181, doi:10.5194/cp-5-171-2009, 2009.

Taricco, C., Vivaldo, G., Alessio, S., Rubinetti, S., and Mancuso, S.: A high-resolution $\delta^{18} \mathrm{O}$ record and Mediterranean climate variability, Clim. Past, 11, 509-522, doi:10.5194/cp-11-509-2015, 2015.

Ternois, Y., Sicre, M. A., Boireau, A., Marty, J. C., and Miquel, J. C.: Production pattern of alkenones in the Mediterranean Sea, Geophys. Res. Lett., 23, 3171-3174, 1996.

Thornalley, D. J. R., Elderfield, H., and McCave, I. N.: Holocene oscillations in temperature and salinity of the surface subpolar North Atlantic, Nature, 457, 711-714, doi:10.1038/nature07717, 2009. 
Touchan, R., Xoplaki, E., Funkhouser, G., Luterbacher, J., Hughes, M. K., Erkan, N., Akkemik, Ü., and Stephan, J.: Reconstructions of spring/summer precipitation for the Eastern Mediterranean from treering widths and its connection to large-scale atmospheric circulation, Clim. Dynam., 25, 75-98, 2005.

Touchan, R., Akkemik, Ü., Hughes, M. K., and Erkan, N.: May-June precipitation reconstruction of southwestern Anatolia, Turkey during the last 900 years from tree rings, Quaternary Res., 68, 196-202, 2007.

Trouet, V., Esper, J., Graham, N. E., Baker, A., Scourse, J. D., and Frank, D. C.: Persistent positive North Atlantic Oscillation mode dominated the Medieval Climate Anomaly, Science, 324, 78-80, doi:10.1126/science.1166349, 2009.

Trouet, V., Scourse, J. D., and Raible, C. C.: North Atlantic storminess and Atlantic Meridional Overturning Circulation during the last Millennium: reconciling contradictory proxy records of NAO variability, Global Planet. Change, 84-85, 48-55, doi:10.1016/j.gloplacha.2011.10.003, 2012.

Tsimplis, M. N. and Baker, F.: Sea level drop in the Mediterranean Sea: an indicator of deep water salinity and temperature changes?, Geophys. Res. Lett., 27, 1731-1734, 2000.

Tsimplis, M. N. and Josey, S. A.: Forcing of the Mediterranean Sea by atmospheric oscillations over the North Atlantic, Geophys. Res. Lett., 28, 803-806, 2001.

Tsimplis, M. N. and Rixen, M.: Sea level in the Mediterranean Sea: the contribution of temperature and salinity changes, Geophys. Res. Lett., 29, 1-4, doi:10.1029/2002GL015870, 2002.

Vallefuoco, M., Lirer, F., Ferraro, L., Pelosi, N., Capotondi, L., Sprovieri, M., and Incarbona, A.: Climatic variability and anthropogenic signatures in the Gulf of Salerno (southern-eastern Tyrrhenian Sea) during the last half millennium, Rend Lincei, 23, 13-23, doi:10.1007/s12210-011-0154-0, 2012.

van Raden, U. J., Groeneveld, J., Raitzsch, M., and Kucera, M.: $\mathrm{Mg} / \mathrm{Ca}$ in the planktonic foraminifera Globorotalia inflata and Globigerinoides bulloides from Western Mediterranean plankton tow and core top samples, Mar. Micropaleontol., 78, 101-112, doi:10.1016/j.marmicro.2010.11.002, 2011.
Vargas-Yáñez, M., Moya, F., García-Martínez, M. C., Tel, E., Zunino, P., Plaza, F., Salat, J., and Pascual, J.: Climate change in the Western Mediterranean Sea 1900-2008, J. Marine Syst., 82, 171-176, doi:10.1016/j.jmarsys.2010.04.013, 2010.

Velasco, J. P. B., Baraza, J., and Canals, M.: La depresión periférica y el lomo contourítico de Menorca: evidencias de la actividad de corrientes de fondo al N del Talud Balear, Geogaceta, 20, 359$362,1996$.

Versteegh, G. J. M., de Leeuw, J. W., Taricco, C., and Romero, A.: Temperature and productivity influences on $\mathrm{U}_{37}^{K^{\prime}}$ and their possible relation to solar forcing of the Mediterranean winter, Geochem. Geophy. Geosy., 8, Q09005, doi:10.1029/2006GC001543, 2007.

Villanueva, J., Pelejero, C., and Grimalt, J. O.: Clean-up procedures for the unbiased estimation of $\mathrm{C}_{37}$ alkenone sea surface temperatures and terrigenous n-alkane inputs in paleoceanography, $\mathrm{J}$. Chromatogr., 757, 145-151, 1997.

Wallace, J. M. and Gutzler, D. S.: Teleconnections in the geopotential height field during the Northern Hemisphere winter, Mon. Weather Rev., 109, 784-812, 1981.

Wassenburg, J. A., Immenhauser, A., Richter, D. K., Niedermayr, A., and Riechelmann, S.: Moroccan speleothem and tree ring records suggest a variable positive state of the North Atlantic Oscillation during the Medieval Warm Period, Earth Planet. Sc. Lett., 375, 291-302, doi:10.1016/j.eps1.2013.05.048, 2013.

Wright, H. E.: Global Climates since the Last Glacial Maximum, Minnesota University Press, Minneapolis, 1994.

Yu, J., Elderfield, H., Greaves, M., and Day, J.: Preferential dissolution of benthic foraminiferal calcite during laboratory reductive cleaning, Geochem. Geophy. Geosy., 8, Q06016, doi:10.1029/2006GC001571, 2007. 